\title{
Does the Chemical Diversity of the Order Haplosclerida (Phylum Porifera: Class Demospongia) Fit with Current Taxonomic Classification?
}

Authors

Affiliations
Marie-Aude Tribalat ${ }^{1}$, Maria V. Marra ${ }^{2}$, Grace P. McCormack ${ }^{2}$, Olivier P. Thomas ${ }^{1,3}$

' Géoazur UMR Université Nice Sophia Antipolis-CNRS-IRD-OCA, Valbonne, France

${ }^{2}$ National University of Ireland Galway, Zoology, School of Natural Sciences, University Road, Galway, Ireland

${ }^{3}$ National University of Ireland Galway, Marine Biodiscovery, School of Chemistry, University Road, Galway, Ireland
Key words

- sponges

- Haplosclerida

- alkaloids

- polyacetylenic

- chemotaxonomy

\section{Abstract}

\section{$\nabla$}

Sponges and their associated microbiota are well known to produce a large diversity of natural products, also called specialized metabolites. In addition to their potential use in the pharmaceutical industry, these rather species-specific compounds may help in the classification of some particular sponge groups. We review herein compounds isolated from haplosclerid sponges (Class Demospongia, Order Haplosclerida) in order to

\section{Introduction}

\section{$\nabla$}

Sponges (Phylum Porifera) are sessile invertebrates distributed in most aquatic ecosystems. In marine areas like the Caribbean Sea, they may represent the largest substrate cover and/or the largest organic biomass of living organisms, thus contributing significantly to several nutrient cycles due to their outstanding filtering capabilities $[1,2]$. In addition, during their long evolutionary history, most, if not all, of the diverse species of this group ( $>8000$ described species to date) together with their associated microbiota have developed unique metabolic pathways leading to a huge diversity of natural products, also called specialized metabolites [3]. Taxonomic classification in this particular group of marine invertebrates is still highly challenging due to a paucity of morphological characters and a discrepancy between molecular and morpological data in many cases. For this reason, biochemical information has been recently used as a complementary tool (particularly within the framework of targeted or untargeted metabolomic approaches), leading to the recent concept of integrative systematics [4].

Within the Class Demospongiae, sponges belonging to the Order Haplosclerida are considered among the most prolific sources of bioactive help in the revision of this large group of marine invertebrates. We focus only on 3-alkylpyridine derivatives and polyacetylenic compounds, as these two groups of natural products are characteristic of haplosclerid species and are highly diverse. A close collaboration between chemists and biologists is required in order to fully apply chemotaxonomical approaches, and whenever possible biological data should include morphological and molecular data and some insight into their microbial abundance. marine natural products, including alkaloids, polyacetylenes, or terpene derivatives. This group is also one of the most diverse of the sponge groups in terms of numbers of species and habitats, and its members also have few distinguishing morphologial characteristics. The current classification of the order as outlined in Systema Porifera, based primarily on morphology, is comprised of three suborders [two marine (Haplosclerina and Petrosina) and one freshwater (Spongillina)]. The marine suborders together comprise six families; Callyspongiidae, Chalinidae, Niphatidae, Petrosiidae, Phloeodictyidae, and Calcifibrospongiidae [5]. Analysis of sterol chemistry had indicated possible difficulties with their classification [6], suggesting patterns of relatedness that did not agree with morphological data, while in contrast, a review of 3-alkylpiperidine alkaloids appeared to agree with the current classification [7]. Subsequent molecular phylogenetic studies reveal an evolutionary history that is not completely compatible with Systema Porifera, indicating that the freshwater sponges belong elsewhere in the Demospongiae, and that while the marine Haplosclerida do form a clade, the suborders and the families (where there is enough data) are polyphyletic [8]. For this reason, a reassessment of the Order Haplosclerida is underway by multiple research groups, as an assessment of chemical 
diversity may help in the development of a robust integrative classification of the group and, in return, current systematic studies in this group may also direct the search for related compounds of interest.

This review will focus on two major classes of specialized metabolites found in the Order Haplosclerida (3-alkylpyridine derivatives and polyacetylene derivatives) and will discuss them in view of the currently accepted classification for five of the six families described in Systema Porifera [5], with no compound being reported so far from sponges of the sixth family Calcifibrospongiidae [9]. Sterols and fatty acids have been reported for some members of this group in 1994 [6], and the large chemical diversity produced by this prolific sponge group was last collated in 1996 for 3-alkylpiperidine derivatives [7]. This review is not aimed to be exhaustive but discusses representatives of 3-alkylpyridine derivatives and polyacetylene derivatives. Given that they are both widely distributed amongst haplosclerid species, are largely restricted to this group, and are rather unique in the field of natural products, we consider that focusing our review on these two chemical families provides ample information to help identify discrepancies in the classification, areas for focus in the construction of a revised integrative classification and valuable avenues for future research focus.

Major issues with publishing descriptions of compounds from species that have not been fully identified will become apparent. This issue is relevant not only for the group of marine sponges included here, but for any organism of interest for bioprospecting. Accompanying morphological identification with a DNA sequence is a highly recommended way forward (in addition to deposition of a specimen voucher in a respected institute/muse$\mathrm{um})$. We intend this review to encourage better connections between chemists and biologists in an effort to identify novel compounds of interest while also striving to understand the origins and evolution of the same. A solid taxonomic description and classification will help in the rational collection of closely related species that will produce a large diversity of analogues of a targeted natural product family. Greater collaborative efforts will therefore increase avenues for identification of bioactive compounds, increase the likelihood of finding exploitable sources and perhaps even a biotechnological route for production. Knowledge of the complex comparative chemistry will assist in unravelling the controversial systematics specifically within the Order Haplosclerida, but will also lead to fruitful considerations in terms of chemotaxonomy within the phylum itself (Porifera, the sponges).

\section{Distribution of Simple 3-Alkylpyridine Derivatives in the Haplosclerida \\ $\nabla$}

Several 3-alkylpyridine derivatives have been isolated from the Haplosclerida, including in some cases the coupling of one or more similar moieties. This group of compounds is differentially distributed across Niphatidae, Callyspongiidae, Chalinidae, and Petrosiidae, but they are not yet reported from confirmed members of the Phloeodictyidae. The presence/absence of these classes of compounds in haplosclerid sponges are summarized in $\odot$ Table 1.

\section{Family Niphatidae}

Within the family Niphatidae, an outstanding diversity of alkaloids has been isolated from members of the genus Amphimedon. Monomers of 3-alkylpyridines named hachijodines E-G as well as glycosylated monomers named amphimedosides A-E were isolated from Amphimedon sp. collected off Hachijo-Jima Island (Japan; - Fig. 1) [10,11]. Additional mono- and dimers, pyrinodemins B-I, were reported from Amphimedon sp. found in the same area (Nakijin, Okinawa) along with a high number of dimers bearing a hydroxylamine moiety, starting with the bis-3alkylpyridine derivative pyrinodemin $\mathrm{A}$ and nakinadines $\mathrm{A}-\mathrm{F}$ (with a $\beta$-aminoacid) [12-16]. All of the compounds mentioned were found to exhibit cytotoxicity. Niphates sp. yielded some mono-3-alkylpyridine derivatives named niphatynes $\mathrm{A}-\mathrm{B}$, again from the Northwestern Pacific (Fiji; O Fig. 2) [17], and Kobayashi's group more recently described some very close analogues named niphatesines $\mathrm{A}-\mathrm{H}$ from a Japanese sponge of the same genus ( Fig. 2) $[18,19]$. Pyrinadines $A-G$ have been isolated from Cribrochalina sp., also from the Japanese coast ( $\bullet$ Fig. 2) [20,21]. It is not known if the two Amphimedons or Niphates sp. mentioned here are the same species or two separate species in each case given that the specimens were collected in the same geographical area. Comparison of the specimen vouchers from the various studies will have to be performed to confirm if this is the case and preferably also comparison of DNA sequences.

It would appear that simple mono- and bis-3-alkylpyridine derivatives are restricted to species belonging to the genera Amphimedon, Cribrochalina, and Niphates, all belonging to the family Niphatidae ( Table 1). While molecular data confirms that certain Niphates and Amphimedon species are related to each other, the position of Cribrochalina and Pachychalina in relation to other members of the Niphatidae family remains unresolved [22]. As more focus is placed on resolving haplosclerid taxonomy, and compounds are isolated from more fully described species, it will be interesting to confirm if this pattern remains.

Also, within the family Niphatidae, a dimeric cyclostellettamine (3 alkylpyridiniums) was isolated from the Northwestern Pacific sponge Amphimedon compressa [23]. Complex mixtures of polymeric halitoxins were isolated from several species present in the Northern Caribbean (Haliclona. rubens, H. viridis and H. erina) that later were classified as A. compressa, Amphimedon viridis, and Amphimedon erina ( Fig. 3) [24]. Later, analogous and bioactive polymers named amphitoxins were isolated as major constituents of $A$. compressa from the Caribbean $[25,26]$. Some trimeric 3-alkylpyridinium salts named niphatoxins A-B were isolated from Niphates sp. collected in the Red Sea by Talpir et al. (○ Fig. 3) [27]. No DNA sequence has been generated yet for $A$. erina, and while molecular data does not cluster $A$. compressa and $A$. viridis directly together, they are both placed in the same subgroup (Clade $C$ ), and are thus related to each other and with Niphates species $[8,22]$. The chemical content of the Southwestern Atlantic (Brazil) sponge Pachychalina alcaloidifera also includes the presence of antimicrobial and antimycobacterial cyclostellettamines A-K (๑ Fig.3) [28,29]. In addition, C-C and $\mathrm{C}-\mathrm{N}$ bis- and tris-3-alkylpyridinium derivatives named pachychalines A-C were isolated from Pachychalina sp. collected in the Northwestern Atlantic (Caribbean; O Fig. 3) [30]. Relationships of these Pachychalina species to each other and to other Haplosclerida have not yet been resolved using morphological and molecular data. 
Table 1 Distribution of 3-alkylpyridine derivatives and polyacetylenic compounds within Haplosclerida sponges.

\begin{tabular}{|c|c|c|c|c|c|c|}
\hline & $\begin{array}{l}\text { 3-Alkyl- } \\
\text { pyridine }\end{array}$ & $\begin{array}{l}\text { 3-Alkyl- } \\
\text { pyridiniums }\end{array}$ & $\begin{array}{l}\text { Simple C4-C5' bis- } \\
\text { 3-alkylpiperidine }\end{array}$ & $\begin{array}{l}\text { Complex } \mathrm{C}^{-} \mathrm{C5}^{\prime} \text { bis- } \\
\text { 3-alkylpiperidine }\end{array}$ & Manzamines & Polyacetylenes \\
\hline \multicolumn{7}{|l|}{ Callyspongiidae } \\
\hline Arenosclera brasiliensis & & & $x$ & & & \\
\hline Callyspongia fistularis & & & & & & $\mathrm{x}$ \\
\hline Callyspongia pseudoreticulata & & & & & & $x$ \\
\hline Callyspongia ridleyi & & $x$ & & & & \\
\hline Callyspongia siphonella & & & & & & $x$ \\
\hline Callyspongia truncata & & & & & & $x$ \\
\hline Callyspongia sp. & & $x$ & & & & $x$ \\
\hline Siphonochalina sp. & & & & & & $x$ \\
\hline \multicolumn{7}{|l|}{ Chalinidae } \\
\hline Haliclona densaspicula & & & & $x$ & & \\
\hline Haliclona fulva & & & & & & $\mathrm{x}$ \\
\hline Haliclona osiris & & & & & & $x$ \\
\hline Haliclona sarai & & & & $x$ & & \\
\hline Haliclona viscosa & & $\mathrm{x}$ & $\mathrm{x}$ & & & \\
\hline Haliclona (Haliclona) & & & & & & $x$ \\
\hline Haliclona sp. & $x$ & $x$ & $x$ & & $x$ & $x$ \\
\hline Haliclona (Reniera) & & $x$ & & $x$ & & \\
\hline \multicolumn{7}{|l|}{ Niphatidae } \\
\hline Amphimedon sp. & $x$ & $x$ & $x$ & & $x$ & \\
\hline Cribrochalina dura & & & & & & $x$ \\
\hline Cribrochalina vasculum & & & & & & $x$ \\
\hline Cribrochalina sp. & $x$ & & & & & \\
\hline Niphates lunisimisis & & & & & & $x$ \\
\hline Niphates sp. & $\mathrm{x}$ & $x$ & & & & $x$ \\
\hline Pachychalina alcaloidifera & & $x$ & $x$ & $x$ & & \\
\hline Pachychalina sp. & & $x$ & & & & \\
\hline \multicolumn{7}{|l|}{ Petrosiidae } \\
\hline Acanthostrongylophora ingens & & & $x$ & & $x$ & \\
\hline Acanthostrongylophora sp. & & & & & $x$ & \\
\hline Neopetrosia exigua & & & $x$ & & & \\
\hline Neopetrosia proxima & & & $x$ & & & \\
\hline Neopetrosia seriata & & & $x$ & & & \\
\hline Petrosia corticata & & & & & & $x$ \\
\hline Petrosia ficiformis & & & & & & $x$ \\
\hline Petrosia solida & & & & & & $x$ \\
\hline Petrosia strongylata & & & & & & $x$ \\
\hline Petrosia volcano & & & & & & $x$ \\
\hline Petrosia (Strongylophora) & & & & & & $x$ \\
\hline Petrosia sp. & & & & & & $x$ \\
\hline Xestospongia muta & & & & & & $x$ \\
\hline Xestospongia testudinaria & & & & & & $x$ \\
\hline Xestospongia sp. & & & & & $x$ & $x$ \\
\hline \multicolumn{7}{|l|}{ Phloeodictyidae } \\
\hline Oceanapia triangulata & & & & & & $x$ \\
\hline Oceanapia sp. & & & & & & $x$ \\
\hline
\end{tabular}

\section{Family Callyspongiidae}

Alkylation at the nucleophilic nitrogen $\mathrm{N}-1$ of the pyridine leading to 3-alkylpyridinium salts is observed in some species of this family. A tris-3-alkylpyridine derivative called niphatoxin C was found in Callyspongia sp. from the Western Pacific (Northwestern Australia), while Buchanan et al. showed the presence of 3-alkylpyridinium polymeric salts from Callyspongia (Toxochalina) ridleyi also collected in the Western Pacific (Papua New Guinea; - Fig. 4) [31]. These compounds with MW between 5 and $6 \mathrm{kDa}$ cause an irreversible membrane potential depolarization.

In some particular cases, 3-alkylpyridiniums are functionalized through reduction of the aromatic ring leading to highly reactive iminium/enamines intermediates that most commonly lead to the coupling of two units through a $\mathrm{C}-4 / \mathrm{C}-5^{\prime}$ bond. This function to connect the two chemical moieties is highly specific and the capability is present only in Haplosclerida and within this group in only a small number of species. The presence of this enzymatic capacity is likely to have phylogenetic significance and thus represents a link between chemistry and taxonomy. Within the family Callyspongiidae, Torres et al. [32] described the arenosclerins $\mathrm{A}, \mathrm{B}$, and $\mathrm{C}$ but also haliclonacyclamine $\mathrm{E}$, macrocylic bis-3-alkylpiperidine derivatives from the Southwestern Pacific sponge Arenosclera brasiliensis ( $\odot$ Fig. 5) [32]. Inversion of configurations at several asymmetric centers is intriguing and suggests a nonspecificity of the enzymes involved. Later, the same authors reported some antibacterial activities of arenosclerins but also some cytotoxic activities against tumoral cell lines [33]. Arenosclera as a member of the family Callyspongidae is a genus well 


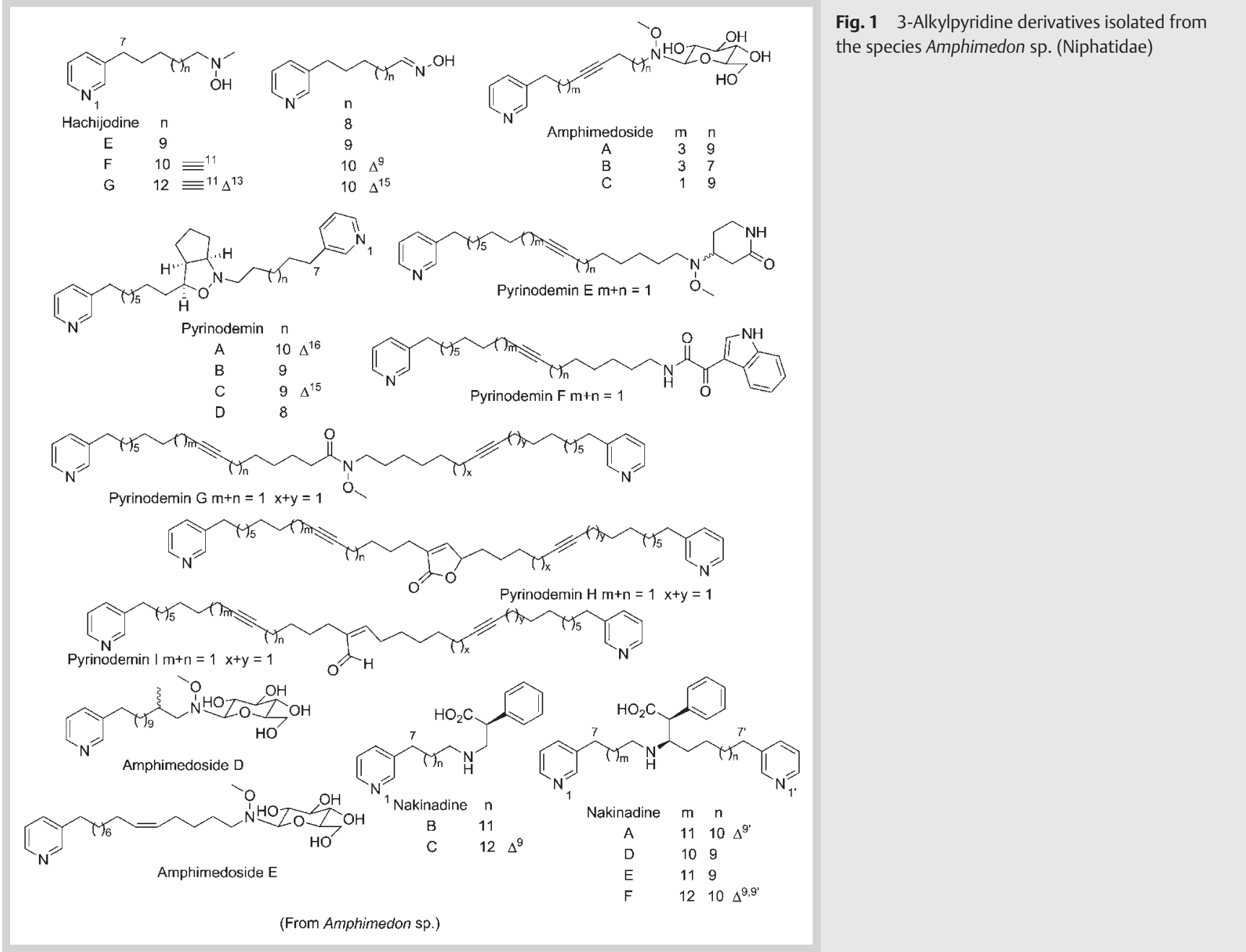

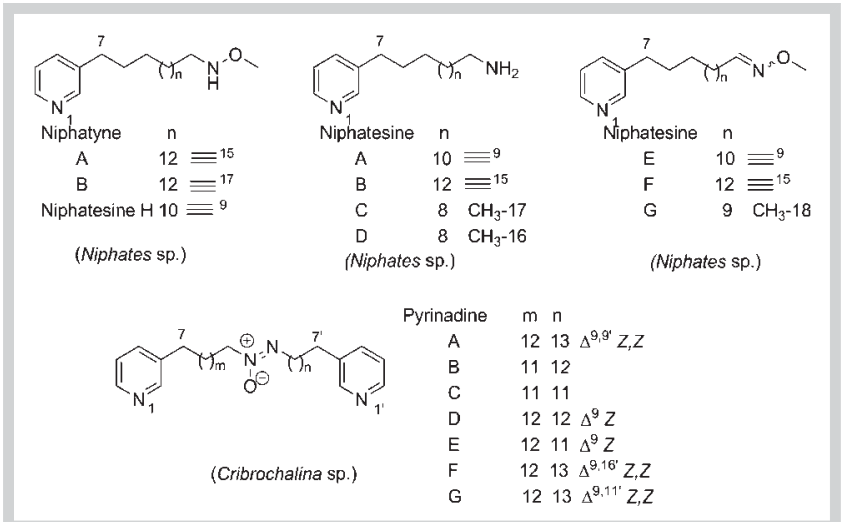

Fig. 2 3-Alkylpyridine derivatives isolated from the species Cribrochalina sp. and Niphates sp. (Niphatidae).

separated from Haliclona (Chalinidae) where bis-3-alkylpiperidines are more commonly found. However, recent molecular studies suggest that members of the Callyspongidae family are closely related to the type species of Haliclona including the only Arenosclera species so far sequenced (Arenosclera heroni) $[8,22$, 34].

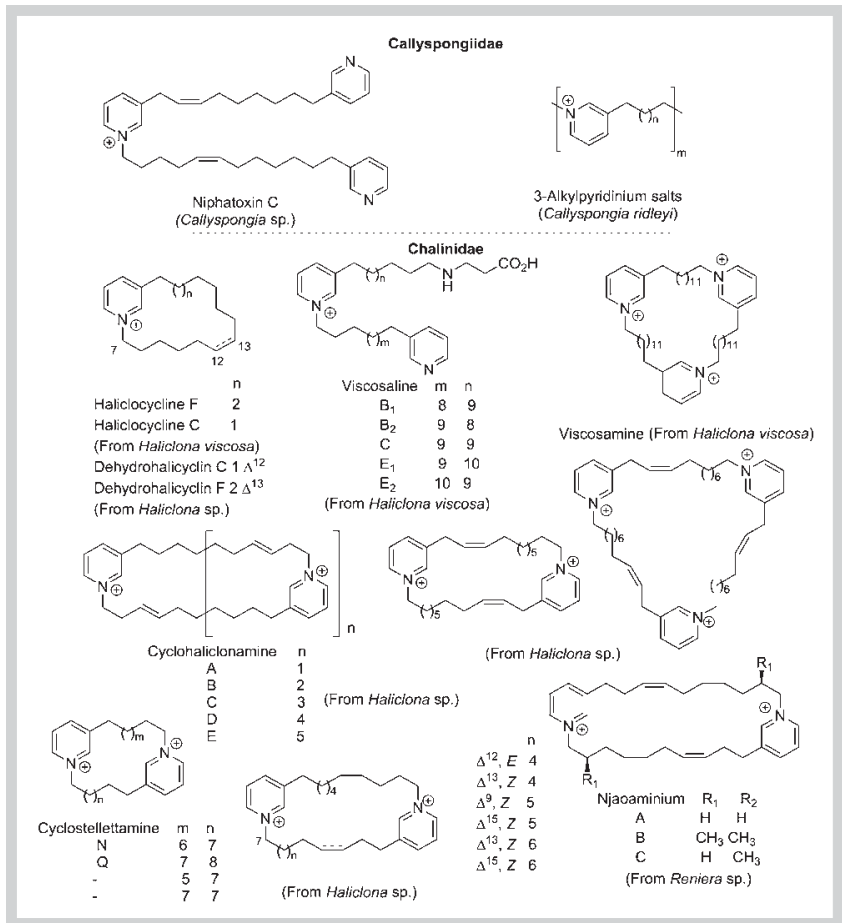

Fig. 3 3-Alkylpyridinium salts isolated from Niphatidae sponges. 


\section{Family Chalinidae}

Within this family, the genus Haliclona is the most represented and diverse, and it has led to an outstanding diversity of natural products, most of them being alkaloids. It is worth underlining, however, that the classification of Haliclona urgently needs revisiting. Molecular data indicates that many very distantly related species have been placed in this genus and will eventually be placed in other families of the Haplosclerida [8]. An impressive diversity of 3-alkylpyridinium natural products has been isolated from the Arctic (Svalbard, Norway) sponge Haliclona (Rhizoniera) viscosa, including monomers like haliclocycline $\mathrm{C}$ and $\mathrm{F}[35,36]$, dimers like the viscosalines [37], and trimers like viscosamine [38] ( $\odot$ Fig. 3). It will be very interesting to determine if related compounds exist in the closely related species $\mathrm{H}$. indistincta (currently being investigated by the authors).

Many additional compounds have been isolated from unidentified Haliclona species (listed all together as Haliclona sp. in $\bullet$ Table 1). The compounds so far isolated include cyclohaliclonamines A-E, which are cyclic and polymeric 3-alkylpyridinium salts isolated from a Okinawan species [39]; dimeric and trimeric unsaturated cyclized 3-alkylpyridiniums from a Guatemalan species [40]; a large diversity of bis-3-alkylpyridiniums of the cyclostellettamine type from a Korean species [41]; cyclic monomers called dehydrohalicyclins $\mathrm{C}$ and $\mathrm{F}$ from a Southeastern Pacific (New Zealand) Haliclona sp. [42] (๑ Fig. 4), and finally methylsubstituted cyclostellettamines called njaoaminiums A-C isolated from Reniera sp. (Reniera has been reclassified as a subgenus of Haliclona) collected in the Western Indian ocean [43] ( Fig. 4). All of these results strongly illustrate the high propensity of the Haplosclerida (and perhaps a subgroup within it) to produce 3-alkylpyridinium derivatives and therefore to connect at least two 3-alkylpyridines through the nucleophilic nitrogen atom of at least one pyridine.

While the biosynthesis of the huge polyamine family of sponge alkaloids remains unknown due to the lack of experimental data, we can hypothesize a key role of the polyamine pathway in the construction of bis-3-alkylpyridinium intermediates [44]. Indeed some other alkaloids produced by Chalinidae sponges exhibit a key $\mathrm{N}-\mathrm{C}_{3}-\mathrm{N}$ moiety, e.g., papuamine and haliclonadiamine, epimers isolated from possibly two specimens of the same Haliclona sp. from the Western Pacific (Papua New Guinea and Palau; - Fig. 6) $[45,46]$. Halitulins are macrocyclic tertiary amines linked to aromatic components. These cytotoxic compounds were identified by Kashman et al. [47] from Haliclona tulearensis in the Southwestern Indian Ocean (Madagascar). Later, isomer and macrocyclic amines named haliclorensins were isolated from the same species, suggesting their implication in the biosynthesis of these bioactive alkaloids ( Fig. 6) [47-50].

The family Chalinidae has led to the largest diversity of bis-3alkylpiperidine derivatives. Rather simple macrocyclic bis-3alkylpiperidines named haliclamines $\mathrm{A}$ and $\mathrm{B}$, a reduced form of the previous 3-alkylpyridinium cyclostellettamines, were isolated from Haliclona sp. growing in the Northwestern Pacific (Japan; - Fig. 5) [51]. Additional haliclamines C-H were isolated from the Arctic sponge $H$. viscosa, thus linking bis-3-alkylpyridiniums with their reduced forms [52-54]. These simple cyclic dimers have led to more complex products after connection of both piperidine cycles through the $\mathrm{C}-4 / \mathrm{C}-5^{\prime}$ carbons. Halicyclamine $\mathrm{A}$ is a $\mathrm{C}-4 / \mathrm{C}-5^{\prime}$ connected bis-3-alkylpiperidine, isolated from Haliclona sp. collected in the Western Pacific (Indonesia; - Fig. 5) [55]. This compound has mainly displayed antimycobacterial activities $[56,57]$. Close analogues named haliclonacycl-

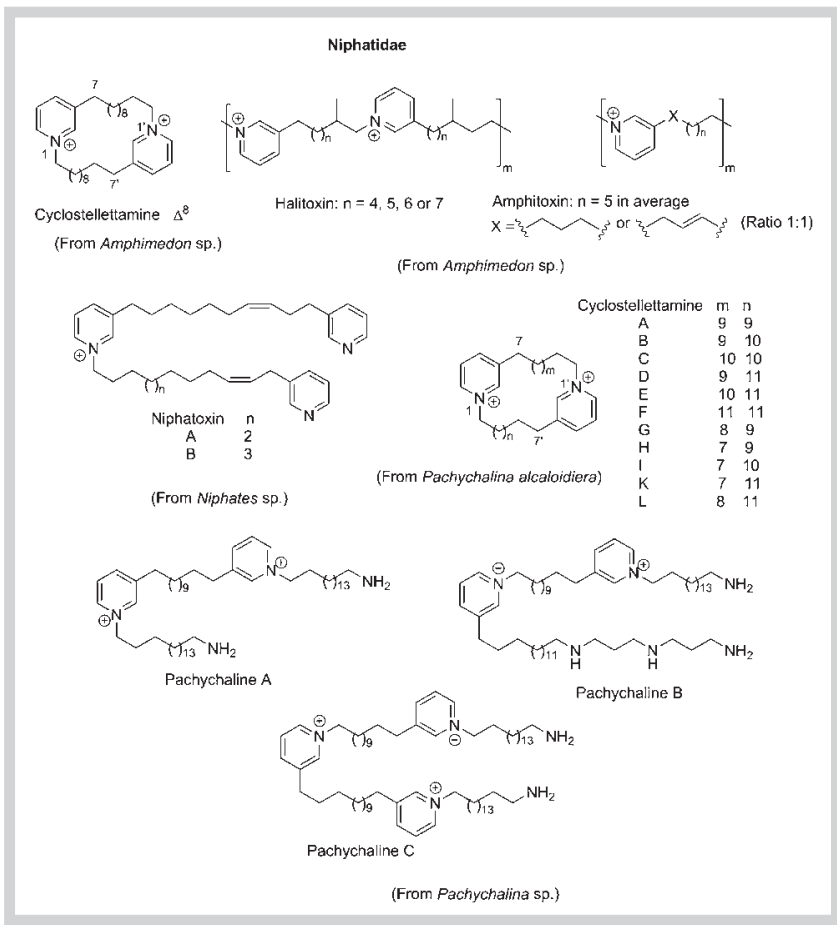

Fig. 4 3-Alkylpyridinium salts isolated from Callyspongiidae and Chalinidae sponges.

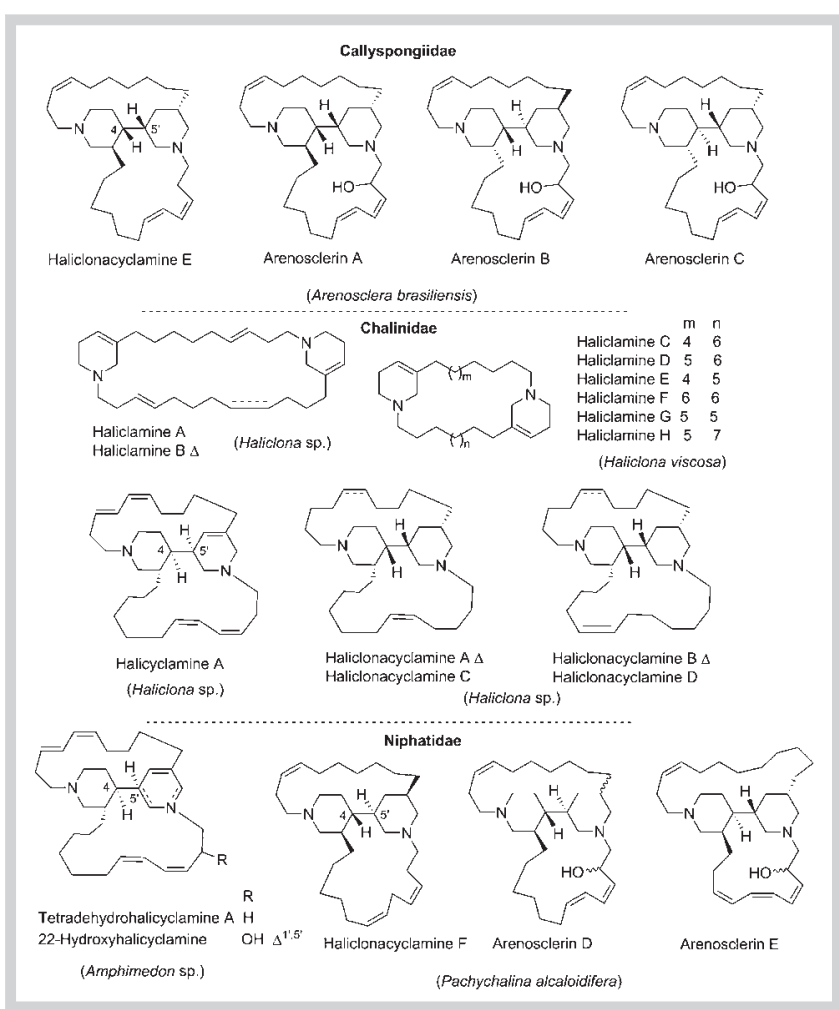

Fig. 5 Simple 3-alkylpiperidines isolated from Callyspongiidae, Chalinidae, and Niphatidae sponges. 
amines A-D were isolated from another Haliclona sp. in the Western Pacific (Australia; O Fig. 5) [58,59]. These compounds were found to be cytotoxic, but also displayed antibacterial and antifungal properties [54].

There are some taxonomic connections between the families Chalinidae and Niphatidae that are currently under investigation, but are relevant to the organization of this review. Very few C-4/ C-5' connected bis-3-alkylpiperidine derivatives have been isolated from the Niphatidae family, but include oxidized analogues of halicyclamines identified in Amphimedon sp. from the Northwestern Pacific (Japan; O Fig. 5) [60] and some bis-3-alkylpiperidine alkaloids identified from Pachychalina alcaloidifera, namely haliclonacyclamine F and arenosclerins D and E ( Fig. 5) [61]. However, $H$. viscosa mentioned above is more related via molecular data to species of Niphates than it is to the type species of Haliclona (Stephens, unpublished PhD thesis, National University of Ireland, Galway). Some of the Australian Haliclona also cluster with Niphates species rather than the type Haliclona species, meaning that this group of compounds may end up being more characteristic of Niphatidae than the Chalinidae in time, and make better sense of the distribution of these specific derivatives.

\section{Family Petrosiidae}

A large diversity of alkaloids has been described from sponges of the genus Acanthostrongylophora, but only a small number of simple bis-3-alkylpiperidines. Garson's group isolated a derivative named acanthocyclamine A from Acanthostrongylophora ingens collected from the Western Pacific (Indonesia; $\odot$ Fig. 7) [62]. Nakagawa et al. [63] first isolated Xestospongins A-D from the Northwestern Pacific (Japan) sponge Xestospongia exigua that was subsequently renamed Neopetrosia exigua († Fig. 7). Araguspongines $\mathrm{A}-\mathrm{H}$ are stereoisomers of these compounds isolated from Xestospongia sp. collected in the same area [64]. An additional xestospongin analogue was further isolated from Xestospongia sp. collected in the Southwestern Pacific (New Caledonia) [65]. Some macrocyclic bis-3-alkylpiperidine named araguspongines $\mathrm{C}$ and $\mathrm{D}$, but also xestospongin $\mathrm{D}$, were also isolated from $N$. exigua collected in the Northeastern Indian Ocean (India; - Fig. 7), while Araguspongin M was isolated from this species collected in Palau and a dimethyl analogue of xestospongin $\mathrm{C}$ was also isolated from this species from the Northwestern Pacific [66-68]. Wei et al. [69] isolated the C-4/C-5' connected neopetrosiamine A from a related species from the Caribbean, i.e., Neopetrosia proxima ( Fig. 7). This compound was shown to exhibit cytotoxic bioactivities, and the relatedness of the two Neopetrosia species is evident also from molecular data [22]. Later, xestoproxamines were described from the same Caribbean sponge (N. proxima) [70]. Petrosins A and B isolated from Petrosia seriata collected in the Western Pacific (Indonesia) are unique reports of 3-alkylpiperidine derivatives from this genus ( Fig. 7) [71,72]. This sponge has been renamed as Neopetrosia seriata and two separate pieces of DNA evidence (a short piece of the $28 \mathrm{~S}$ ribosomal RNA gene and a region of the mitochondrial cytochrome oxidase 1 gene) place this species with another but unnamed Petrosia species [8]. The relationships of both species to other Petrosia or Neopetrosia or indeed any other Haplosclerida currently remain unresolved.

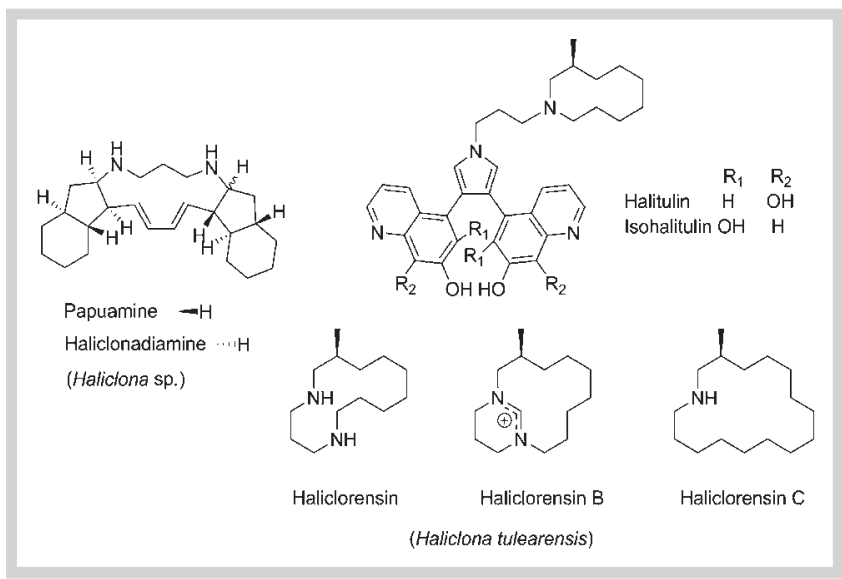

Fig. 6 Polyamines from Chalinidae sponges.

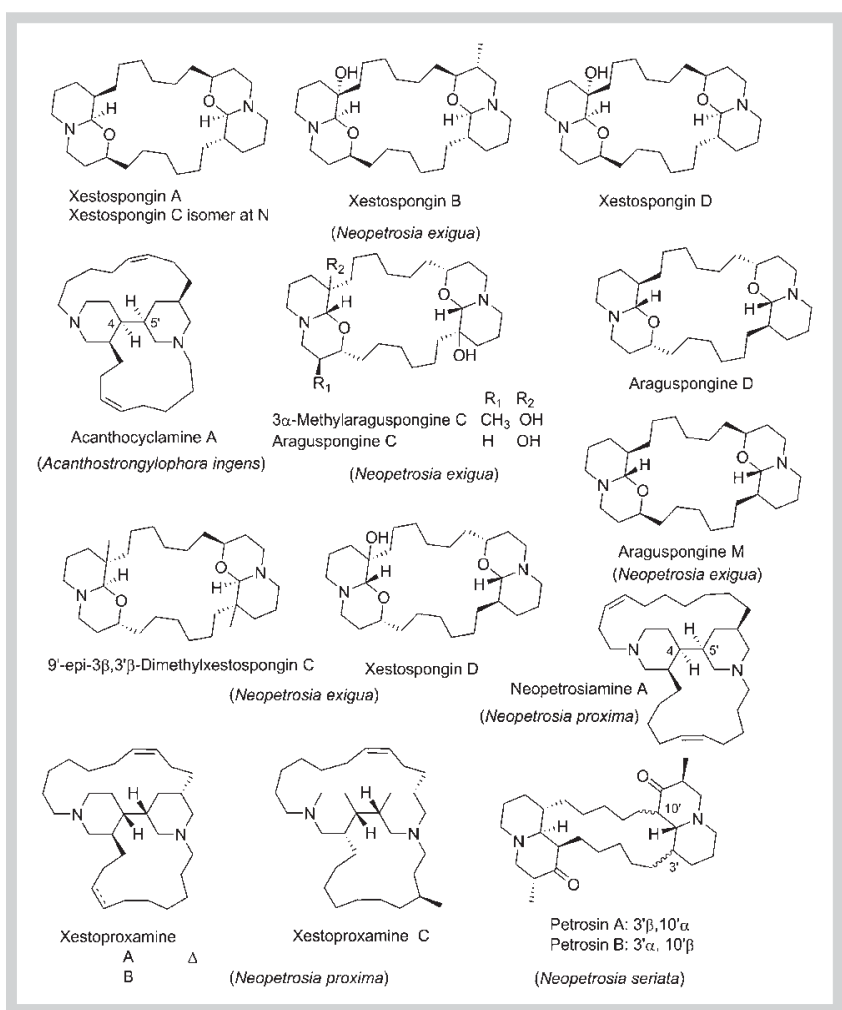

Fig. 7 Simple 3-alkylpiperidines isolated from Petrosiidae sponges.

\section{Distribution of Complex 3-Alkylpiperidine Derivatives in the Haplosclerida \\ $\nabla$}

The complexity of 3-alkylpiperidine derivatives culminates with the biosynthesis of outstanding complex molecules, most of them including the $\mathrm{C}-4 / \mathrm{C}-5^{\prime}$ but also additional $\mathrm{C}-\mathrm{C}$ connections and then becoming real cage compounds. Many such compounds are present in members of Chalinidae and Niphatidae families, which, as mentioned above, require reassessment, e.g., some Haliclona should be renamed and are more closely related to members of the Niphatidae family. Hence, they are treated here in a separate section. Saraines 1-3 and A-C were isolated from the Northern Mediterranean sponge Haliclona (Rhizoniera) sarai 
( Fig. 5) [73,74]. Both piperidine cycles are also connected through the $\mathrm{C}-4 / \mathrm{C}-5^{\prime}$ bond, but in the case of saraines $\mathrm{A}-\mathrm{C}$, other connections were established between both cycles. A large array of biological activities have been described for these compounds [75]. Finally a bis-3-alkylpiperidine derivative called haliclonin A was isolated from Haliclona sp. in the Northwestern Pacific (Korea) [76]. Just like saraines $\mathrm{A}-\mathrm{C}$, this compound exhibits a $\mathrm{C}-2 / \mathrm{C}-3^{\prime}$ bond and one of the piperidines has been opened, maybe after oxidation/hydrolysis processes.

An unusual connection with a quinoline aromatic ring on one alkyl chain is characteristic of the njaoamines A-H isolated from the same Reniera sp. as the njaoaminiums in the Western Indian Ocean ( Fig. 8) $[77,78]$. In these compounds, both piperidine cycles are connected through $\mathrm{C}-4 / \mathrm{C}-5^{\prime}$ as before but also through a second $\mathrm{C}-3 / \mathrm{C}-2$ ' connection. Densanins were isolated from Haliclona densaspicula in the shallow waters of the Northwestern Pacific (Japan) [79]. They are highly complex pyrrole alkaloids, but their biosynthesis may originate from a common bis-3-alkylpiperidine group through contraction of a piperidine. We still observe the usual C-4/C-5' connection between both cycles. Complex bis-3-alkylpiperidine alkaloids ingenamine $\mathrm{G}$ and madangamine $\mathrm{F}$ have been isolated from the Southwestern Atlantic sponge Pachychalina alcaloidifera, a species currently placed in the family Niphatidae via morphology (๑ Fig. 8) [28,61, 80]. Preliminary molecular data suggest that $H$. sarai is actually more closely related to species of Niphates than to the Haliclona species (H. oculata). Much more work relating to morphology, DNA, and chemical evidence is again needed to understand the origin and development of such compounds. Despite the complexity of the chemistry in $P$. alcaloidifera, the authors were not able to isolate more advanced derivatives belonging to the manzamine alkaloids from this sponge.

In some cases, the opening of one piperidine ring can lead to condensation of aromatic rings through Pictet-Spengler condensation. This is the case for the well-known manzamines A and B that maintain the $\mathrm{C}-4 / \mathrm{C}-5^{\prime}$ connection and which were first isolated from Haliclona sp. in the Northwestern Pacific (Japan; - Fig. 9) [81,82]. Manzamine C, isolated in the same study, lacks the 3-alkylpiperidine parts but keeps the $\beta$-carboline. These compounds are among the most promising natural antiparasitic and antitumoral compounds to date [83]. A close analogue called manzamine $Y$ was isolated later from a similar sponge (๑ Fig. 9) [84]. At the same time, similar compounds named keramamimes A and B were isolated from Pellina sp. [85]. However, its taxonomic status has not been clearly confirmed and it may be the same Haliclona species mentioned above. The structure of keramamime $B$ has subsequently been revised and corresponds to manzamine F, a structure much more consistent with biosynthetic hypotheses ( $\odot$ Fig. 9) [86].

A large diversity of manzamine alkaloids has also been isolated from the family Niphatidae and especially from one Amphimedon species. First, 6-hydroxymanzamine and 3,4-dihydromanzamine were isolated from Amphimedon sp. in the Northwestern Pacific (Japan) ( Fig. 9) [87]. Keramaphidin B is a plausible biogenetic precursor of the bis-3-alkylpiperidine parts of manzamine [88], while keramaphidin C and keramamine C [89] are precursors of manzamine $C(\bullet$ Fig. 9 ), and ircinols are antipode of the putative biosynthetic precursor of the manzamines [90]. Tetrahydro- $\beta$ carbolines manzamines $\mathrm{H}$ and $\mathrm{L}$ were isolated from the same species of Amphimedon ( Fig. 9) [91] and additional manzamines were isolated later: 3,4-dihydromanzamine J, 3,4-dihydro-6hydroxymanzamine A and manzamine M [92]. Finally, manz-

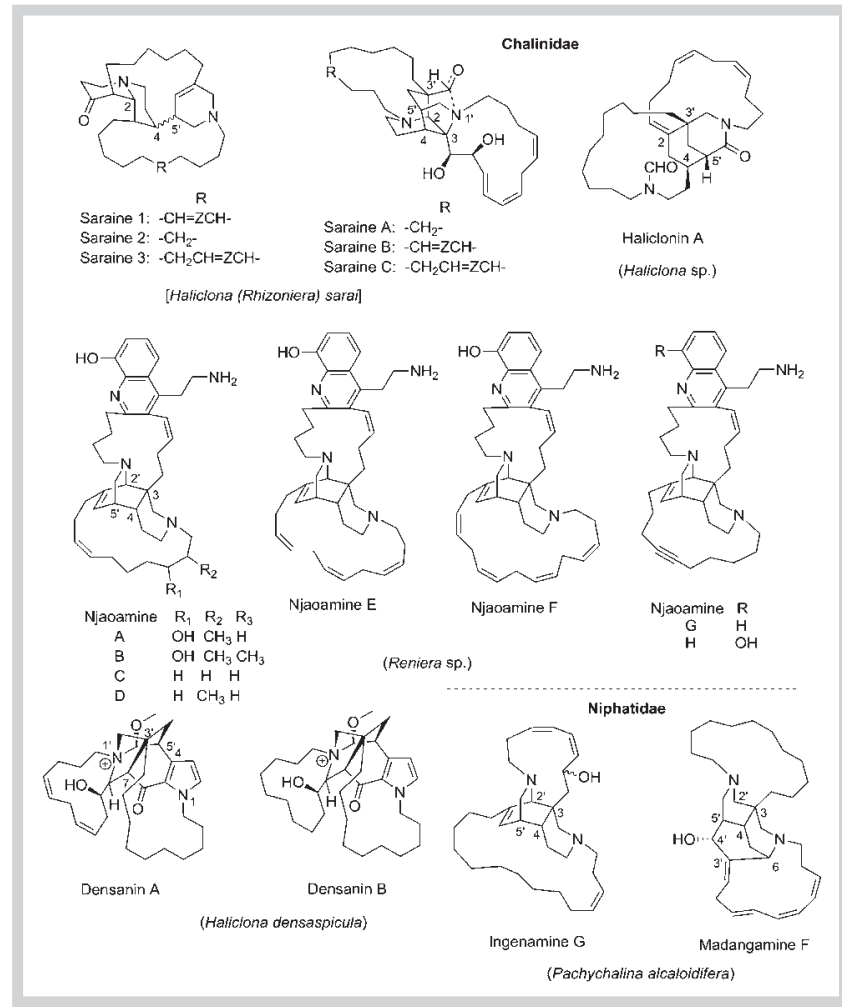

Fig. 8 Complex bis-3-alkylpiperidines from Chalinidae sponges.

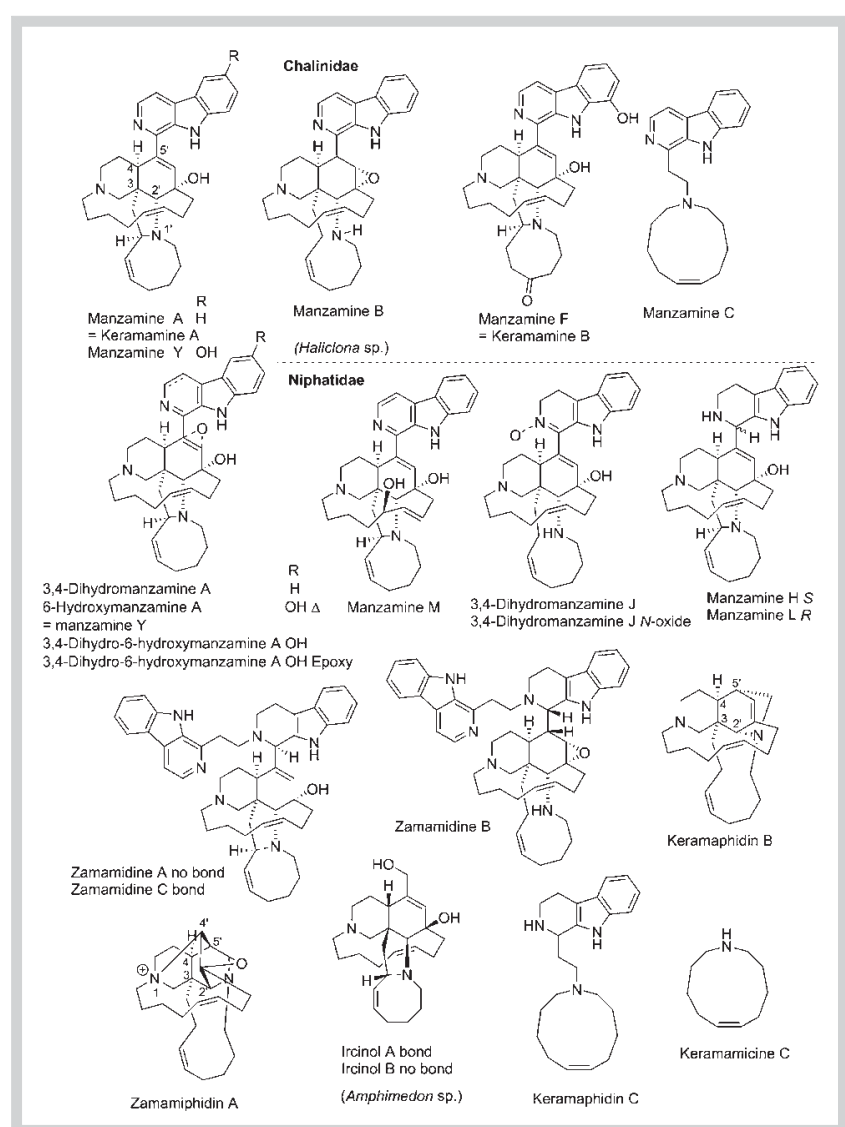

Fig. 9 Manzamine alkaloids isolated from Chalinidae and Niphatidae sponges. 
amine derivatives condensed with a second $\beta$-carboline unit gave a name to the zamamidines, but also 3,4-dihydromanzamine J $\mathrm{N}$-oxide and 3,4-dhydro-6-hydroxymanzamine A [93]. Finally a derivative of keramaphidin B named zamamiphidin A was isolated from the same Amphimedon sp. (๑ Fig. 9) [94].

Isolated from Acanthostrongylophora sp., a sponge currently placed in the family Petrosiidae and collected in the Northwestern Pacific, are quite a number of manzamines, i.e., ircinol A, ircinal A, 12,28-oxaircinal A, manzamine A, manzamine A $\mathrm{N}$-oxide, 3,4-dihydromanzamine $\mathrm{A} N$-oxide, and 8-hydroxymanzamine A as well as manzamine $\mathrm{B}, 8$-hydroxymanzamine $\mathrm{B}$, manzamine $\mathrm{E}$, 12,34-oxamanzamine $\mathrm{E}$ and both 6-hydroxy derivatives, 12,28oxamanzamine E, manzamine F, manzamine J, 8-hydroxymanzamine J, manzamine $\mathrm{X}, 6$-deoxymanzamine $\mathrm{X}$, and acantholactone ( Fig. 10) [95-97]. It is important to notice here that the extraordinary complex dimer named neo-kauluamine was isolated from this sponge but had also been isolated previously from a species belonging to a new genus (and as yet undescribed) within the Petrosiidae family [98]. The huge pharmacological potential of these compounds showing antimicrobial and antialzheimer activities has been demonstrated [91]. Other researchers demonstrated the presence of manzamine A and its 8-hydroxy derivative as well as a highly original series of acanthomanzamines A$E$ and additional manzamine derivatives like acantholactam and pre-neo-kauluamine ( Fig. 11) from $A$. ingens collected in the same area [99-101]. Two precursors of manzamine alkaloids were isolated from Xestospongia sp. collected in the Western Pacific (Papua New Guinea) and the structure of xestocyclamine A was later revised ( Fig. 11) [102,103]. Finally, a large chemical diversity of complex bis-3-alkylpiperidines was isolated from Xestospongia ingens (Petrosiidae) collected in the Western Pacific (Papua New Guinea). It is worth noting here that the name of this sponge is no longer accepted and instead refers to $A$. ingens already mentioned previously. Ingenamine $A$ was first isolated [104] and then ingamines A and B [105], madangamine A [106], and other analogues (๑ Fig. 11) [107]. The unique alkaloid 8hydroxymanzamine A was isolated from Pachypellina sp. (Phloedictyidae) but this species was later assigned to the same unnamed genus from the Petrosiidae family mentioned above [98, 108].

\section{Distribution of Polyacetylenic Derivatives \\ across the Haplosclerida}

It has been impossible to find a chemical and logical classification of the polyacetylenic compounds produced by members of the Haplosclerida and the chemical structures do not give valuable information for identification of key enzymes leading to their synthesis. A pattern, however, does emerge linking either alkaloid or polyacetylene pathways in each species but never both ( $\bullet$ Table 1). Therefore, we report on a selection of compounds from this group in view of the taxonomic classification of the species in question as we did for the alkaloids.

A large diversity of polyacetylenes, mostly from the aikupikanyne group, was isolated from Callyspongia species, including Callyspongia truncata, Callyspongia pseudoreticulata, and Callyspongia fistularis (Callyspongiidae) [109-115]. Previously classified as Siphonochalina (also Callyspongiidae), C. truncata and Callyspongia siphonella uniquely produce polyacetylenic derivatives [116-118]. The change of genus indicates the difficulty with identifying haploslerid sponges via morphological methods alone.

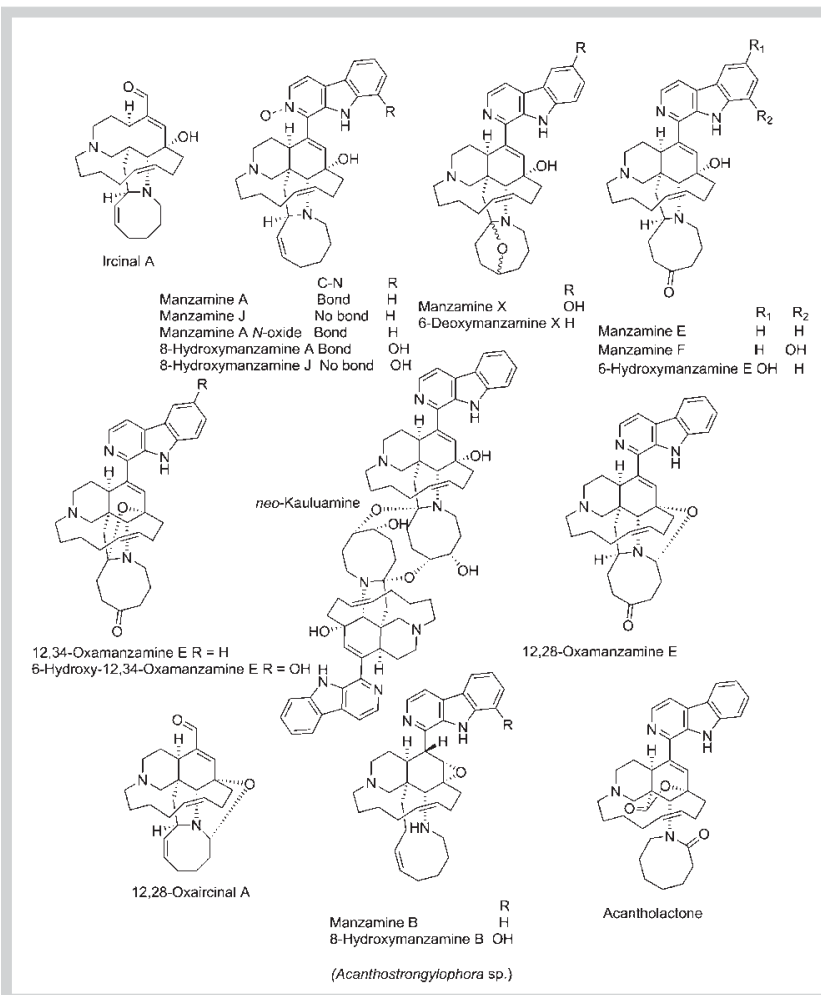

Fig. 10 Manzamine alkaloids from the sponge Acanthostrongylophora sp. (Petrosiidae).

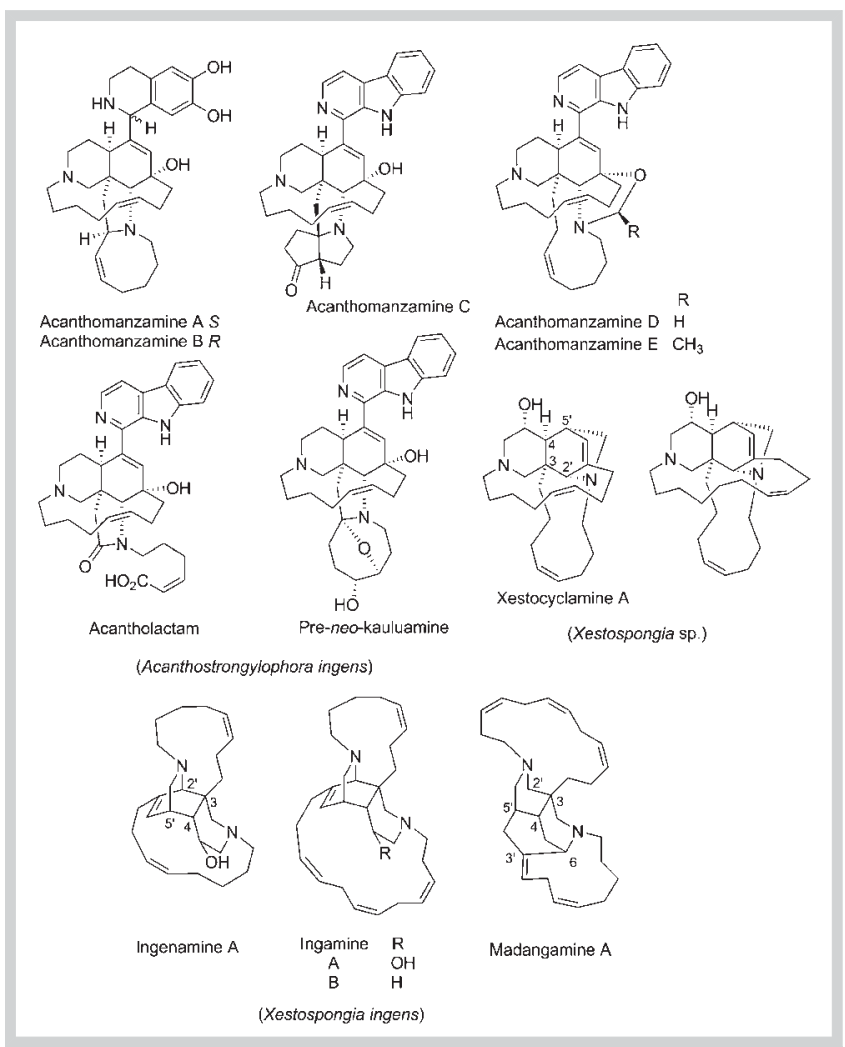

Fig. 11 Manzamine alkaloids from sponges A. ingens and Xestospongia (Petrosiidae). 
From Chalinidae sponges, several renierins followed by fulvinol and the polyhydroxylated fulvynes were isolated from the Mediterranean sponge Haliclona (Halichoclona) fulva [119-121]. Some polyacetylenes were also isolated from Haliclona sp. collected in the Western Pacific (Palau) while polyhydroxylated osirisynes were isolated from $H$. (Reniera) osiris collected in the Northwestern Pacific (China) [122,123]. Other compounds from unidentified Haliclona species include Haliclonyne [124], lembehynes (Northwestern Pacific, Japan) [125,126], Halycinones A and B [127] (Western Pacific, Micronesia), and brominated derivative [128]. Adocia sp. provided adocyacetylenes A-D, and while this genus is now accepted as Haliclona (Haliclona) [129], it is likely that the genus Adocia will be re-errected in the near future (McCormack, unpublished data). How many different species are included in the above list and what their actual final classification will be is therefore as yet unknown and needs attention.

Among the family Niphatidae, the genus Cribrochalina has provided a large diversity of polyacetylenic compounds. Duryne was first isolated from C. dura collected in the Northwestern Atlantic (Bahamas) [130], while the Caribbean sponge C. vasculum afforded several simple acetylenic alcohols, including vasculyne [131-134]. Nepheliosyne B was isolated from Niphates sp. collected in the Western Pacific (New Caledonia) [135], and chlorinated acetylenic compounds were isolated from Haliclona lunisimisis, later renamed Niphates lunisimisis de Jesus \& Faulkner [136].

The family Petrosiidae has yielded a large diversity of polyacetylenic products, mostly from sponges of the genus Petrosia, a genus that, unfortunately, also needs taxonomic revision. The Mediterranean sponge Petrosia ficiformis has afforded a large panel of polyacetylenic derivatives, including petroformynes 110 [137-144], while petrosolic acid was later isolated from Petrosia sp. from the red sea [145]. Aztequynols A and B were isolated from a Caribbean Petrosia sp. [146]. Northwestern Pacific species from this genus have generated many compounds, including Petrosynol and petrosynone isolated from Petrosia sp., [147], brominated derivatives from P. (Petrosia) volcano [148], corticatic acids A-E from P. (Strongylophora) corticata [149,150], petrocortynes A-H and petrosiacetylenes A-D and other analogues from Petrosia sp. collected in Korea [151-157], strongylodiols from P. (Strongylophora) sp. $[158,159]$, polyacetylene carboxylic acids [160], neopetroformynes A-D and later miyakosynes A-F [161, 162], petroacetylene from P. (Petrosia) solida [163], and finally, petrosiols A-E from P. (Strongylophora) strongylata [164].

Research focused on another petrosid genus led to the isolation of some polyacetylenic compounds from the Caribbean sponge Xestospongia muta [165], while several brominated derivatives were isolated from Xestospongia testudinaria from the Southwestern Pacific (Australia) [166-168]. Other compounds isolated from Xestospongia sp. include unsaturated fatty acids [169], melynes A-C [170], a polyhydroxylated derivative named nepheliosyne A analogous to fulvynes and osisirynes [171], and brominated unsaturated fatty acids [172].

With regard to the family Phloedictyidae, their unique isolated compounds were polyacetylenic derivatives, triangulynes $\mathrm{A}-\mathrm{H}$ and pellynols A-D from the Western Pacific sponge (New Caledonia) Oceanapia triangulate $[173,174]$, and another polyacetylene from Oceanapia sp. [175]

\section{Integrating Chemistry and Biology}

\section{$\nabla$}

A large diversity of novel compounds of interest have been isolated from haplosclerid sponges and this group is likely to be a focus of continued efforts in this area for the foreseeable future given the diversity of species and habitats available providing a huge diversity of chemicals in turn. This review provides tantalizing insights into possible patterns of shared structures and biosynthetic pathways between species. However, real insights are hampered by the fact that most species included have not been identified to species and have not been included in any modern phylogenetic study. It is important to convey to chemists about the ever-changing world of taxonomic classification given the new methods being employed, including phylogenetic analysis of DNA sequence data. This is never truer than for haplosclerid sponges. There is an urgent need to revisit the studied sponges to place them in the new phylogenetic classification (including patterns of ancestry and descent between species) being built for demosponges. Only an approach of fully identifying sponges at the species level for analysis of chemistry will provide real additional value to the usual tools of systematics, thus contributing significantly to integrative taxonomy. Marine natural chemists should work tightly with taxonomic specialists (including specifically a phylogenetic approach) of each group in order to publish relevant data. For example, some species groups, i.e., of unidentified Haliclona and Xestospongia species, produce alkaloids but also polyacetylenic compounds, which prevents us from reaching any clear conclusion regarding patterns of distribution of specific compounds across taxonomic groups. However, once understood, the presence of each family of compounds could help significantly in a proper classification and avoid misinterpretation of species identification/classification.

From $\odot$ Table 1, several clues are provided for assisting sponge classification. First of all, the presence of both polyacetylenic and alkaloid compounds have never been reported in a single species. Both biosynthetic genes/pathways cannot, therefore, be present in a species. This observation leads us to suggest a clear separation between species producing alkaloids and species producing polyacetylenes. For example, $C$. ridleyi is the only known species of the genus Callyspongia that does not produce polyacetylenic compounds. In the same way, only one species of Cribrochalina sp. was found to produce alkaloids. This could lead to a clear revision of the taxonomy of these sponges. Finally, Neopetrosia species were found to produce alkaloids, while Petrosia species produce only polyacetylenic compounds. However, these two genera are currently placed in the same family, Petrosiidae, indicating that revision is required at different levels of the taxonomic hierarchy.

One undefined species of Cribrochalina (Niphatidae) produces only 3-alkylpyridine derivatives. Simple alkylation at the nitrogen atom of the pyridine leads to 3-alkylpyridiniums that can polymerize. Only the species of Callyspongia (Callyspongiidae), Niphates, and Pachychalina (Niphatidae) seem to stop the biosynthesis at this step for this group of alkaloids. Because these genera are distinct, revisiting the voucher samples could help to identify similarities between these species. The subsequent ability of some species to reduce the aromatic rings enabling a C- $4 / \mathrm{C}-5^{\prime}$ connection between two cycles is shared by several species, including Arenosclera brasiliensis (Callyspongiidae) and $\mathrm{H}$. viscosa (Chalinidae). Contrary to other families, members of Callyspongiidae seem unable to develop more complex alkaloids. In the same way, Neopetrosia (Petrosiidae) species only produce simple 
bis-3-alkylpiperidine derivatives. Neopetrosia could be hypothesized then to be closer to some Callyspongia sponges, and recent phylogenetic classification suggests that some Neopetrosia are placed within the same major clade as Callyspongia (Clade A) [8, 21]. Much more complex alkaloids are produced by few species distributed in several families, which also raises questions regarding the reliability of the classification. H. densaspicula, H. sarai, a Reniera sp. (Chalinidae), and Pachychalina alcaloidifera (Niphatidae) are able to produce complex alkaloids, but no manzamines have been isolated from these species. It appears that clearly this ability should gather some Haliclona species. As for the extremely complex alkaloid manzamines, members of the genera Acanthostrongylophora (Petrosiidae), Haliclona (Chalinidae), and Amphimedon (Niphatidae) were found to produce them. These compounds are not characteristic of the Petrosiidae, as most species of this family produce only polyacetylenes.

A diversity of polyacetylenic compounds is found distributed across all of the five families of Haplosclerida included so far and their patterns of occurrence should trigger careful examination of the studied species. For example, four Callyspongia species (Callyspongiidae) produce compounds very similar to two Haliclona species (Chalinidae), two Cribrochalina species, and one $\mathrm{Ni}$ phates species (Niphatidae), but most of the polyacetylenic compounds are really representative of Petrosia and Xestospongia genera (Petrosiidae). Recent molecular phylogenies suggest that Callyspongia and some Haliclona fall into one major clade (Clade A) at the base of which appears Cribochalina $[8,22]$. Niphates species fall into a distantly related clade, also with some Haliclona (Clade C), while species from Petrosia and Xestospongia are distributed across multiple clades (but distinct from the aforementioned genera) and are poorly represented on phylogenetic trees drawn from molecular data as yet $[8,22]$.

The value of a chemosystematics approach for haplosclerid sponges has been questioned in the past due to disagreement between patterns of chemical diversity and morphological classification [176]. With molecular data throwing light on possible evolutionary pathways in sponges, it is evident that the morphological classification is flawed and is likely to change, and this is especially true for the Haplosclerida. An additional concern could be the varying influence of microbes residing in sponge tissue, which may be responsible for some of the compounds isolated. A diversity of microbial sequences has been reported from some Haliclona species and Xestospongia, amongst others [177-180], even though these studies do not show the presence of microbes in the sponge tissue nor do they confirm the source of compounds of interest as being from sponge or microbial cells. Sponges filter feed and concentrate microbes and microbial constituents from their environment, and these elements will be present in approaches that only isolate DNA sequences from sponge cells (even though they may only represent food for the sponge). Therefore, the presence of many bacterial DNA sequences in sponges does not equate directly to a sponge-bacterial association or to the production of detectable levels of compounds of interest by said bacteria. Ultrastructural studies on Irish and Mediteranean Haliclona species (Marra, unpublished data) show extremely low numbers of bacterial cells in four species, while an association between one or very few bacteria is evident in three species and many bacterial species are evident in one. Consideration of such patterns in these and other species will also be required to truly understand how patterns of microbial diversity impact patterns of chemical diversity.

\section{Conclusion}

$\nabla$

Our main conclusion is that chemical diversity does not fit with the current classification of this major group of marine sponges, but supports a clear revision of all the species of the Order Haplosclerida included in chemical publications taking into account the presence or absence of key enzymes leading to 3-alkylpyridine derivatives or polyacetylenes. Despite apparent discrepancies there are tantalizing insights that patterns of chemical diversity may well agree in good part with an updated classification that incorporates molecular and other data including morphology. Assessment of the possible bacterial origin of spongederived compounds should also be considered. Three other limitations to this approach are the existence of mistakes made in the identification of the species under investigation, a discrepancy between a classical taxonomic approach utilizing shared sponge morphological characters and the approach that uses molecular phylogenetic methods, and, thirdly, poor sampling of the huge diversity of sponges and the chemistry they contain. However, we believe that this review should help in the further development of an integrative approach between biology and chemistry for this group of sponges. The issues highlighted here are not restricted to the group of marine sponges included, but are relevant to all organisms that are of interest in the search for novel chemistry for whatever reason and where taxonomy is still unresolved. New advances in 'omics' sciences, and especially metabolomic approaches using mass spectrometry and nuclear magnetic resonance with some characteristic signals, could quickly give important clues for integrative systematics.

\section{Conflict of Interest}

$\nabla$

The authors declare no conflict of interest.

\section{References}

1 Zhang F, Blasiak LC, Karolin JO, Powell RJ, Geddes CD, Hill RT. Phosphorus sequestration in the form of polyphosphate by microbial symbionts in marine sponges. Proc Natl Acad Sci USA 2015; 112: 4381-4386

2 De Goeij JM, van Oevelen D, Vermeij MJA, Osinga R, Middelburg JJ, de Goeij AF, Admiraal W. Surviving in a marine desert: the sponge loop retains resources within coral reefs. Science 2013; 342: 108-110

3 Genta-Jouve G, Thomas OP. Sponge chemical diversity: from biosynthetic pathways to ecological roles. Adv Mar Biol 2012; 62: 183-230

4 Cardenas P, Perez T, Boury-Esnault N. Sponge systematics facing new challenges. Adv Mar Biol 2012; 61: 79-209

5 Van Soest RM, Hooper JA. Order Haplosclerida Topsent, 1928. In: Hooper JA, Van Soest RM, Willenz P, editors. Systema Porifera - A guide to the classification of sponges. New York: Springer US; 2002: 831-832

6 Fromont J, Kerr S, Kerr R, Riddle M, Murphy P. Chemotaxonomic relationships within, and comparisons between, the orders Haplosclerida and Petrosida (Porifera: Demospongiae) using sterol complements. Biochem Syst Ecol 1994; 22: 735-752

7 Andersen RJ, van Soest RWM, Kong F. 3-Alkylpiperidine alkaloids isolated from marine sponges in the order Haplosclerida. In: Pelletier SW, editor. Alkaloids: chemical and biological perspectives. Oxford: Pergamon Press; 1996: 301-355

8 Redmond NE, Raleigh J, van Soest RWM, Kelly M, Travers SAA, Bradshaw B, Vartia S, Stephens KM, McCormack GP. Phylogenetic relationships of the marine Haplosclerida (Phylum Porifera) employing ribosomal (28 S rRNA) and mitochondrial cox1, nad1 gene sequence data. PLoS One 2011; 6: e24344

9 Van Soest RWM, Boury-Esnault N, Hooper JNA, Rützler K, de Voogd NJ, Alvarez de Glasby B, Hajdu E, Pisera AB, Manconi R, Schoenberg $C$, Janussen D, Tabachnick KR, Klautau M, Picton B, Kelly M, Vacelet J, Dohrmann M, Díaz MC, Cárdenas P. World Porifera database. Available 
at: http://www.marinespecies.org/porifera. Accessed September 1, 2015

10 Tsukamoto S, Takahashi M, Matsunaga S, Fusetani N, Van Soest RW. Hachijodines A-G: seven new cytotoxic 3-alkylpyridine alkaloids from two marine sponges of the genera Xestospongia and Amphimedon. J Nat Prod 2000; 63: 682-684

11 Takekawa Y, Matsunaga S, van Soest RW, Fusetani N. Amphimedosides, 3-alkylpyridine glycosides from a marine sponge Amphimedon sp. J Nat Prod 2006; 69: 1503-1505

12 Hirano K, Kubota T, Tsuda M, Mikami Y, Kobayashi J. Pyrinodemins B-D, potent cytotoxic bis-pyridine alkaloids from marine sponge Amphimedon sp. Chem Pharm Bull (Tokyo) 2000; 48: 974-977

13 Tsuda M, Hirano K, Kubota T, Kobayashi J. Pyrinodemin A, a cytotoxic pyridine alkaloid with an isoxazolidine moiety from sponge Amphimedon sp. Tetrahedron Lett 1999; 40: 4819-4820

14 Kubota T, Kura K, Fromont J, Kobayashi J. Pyrinodemins G-I, new bis-3alkylpyridine alkaloids from a marine sponge Amphimedon sp. Tetrahedron 2013; 69: 96-100

15 Kura K, Kubota T, Fromont J, Kobayashi J. Pyrinodemins E and F, new 3alkylpyridine alkaloids from sponge Amphimedon sp. Bioorg Med Chem Lett 2011; 21: 267-270

16 Nishi T, Kubota T, Fromont J, Sasaki T, Kobayashi J. Nakinadines B-F: new pyridine alkaloids with a $\beta$-amino acid moiety from sponge Amphimedon sp. Tetrahedron 2008; 64: 3127-3132

17 Quiñoà E, Crews $P$. Niphatynes, methoxylamine pyridines from the marine sponge, Niphates sp. Tetrahedron Lett 1987; 28: 2467-2468

18 Kobayashi J, Zeng CM, Ishibashi M, Shigemori H, Sasaki T, Mikami Y. Niphatesines $\mathrm{E}-\mathrm{H}$, new pyridine alkaloids from the Okinawan marine sponge Niphates sp. J Chem Soc Perkin Trans 1 1992; 11: 1291-1294

19 Kobayashi J, Murayama T, Kosuge S, Kanda F, Ishibashi M, Kobayashi $H$, Ohizumi Y, Ohta T, Nozoe S, Sasaki T. Niphatesines A-D, new antineoplastic pyridine alkaloids from the Okinawan marine sponge Niphates sp. J Chem Soc Perkin Trans 1 1990; 12: 3301-3303

20 Kariya Y, Kubota T, Fromont J, Kobayashi J. Pyrinadines B-G, new bispyridine alkaloids with an azoxy moiety from sponge Cribrochalina sp. Bioorg Med Chem 2006; 14: 8415-8419

21 Kariya Y, Kubota T, Fromont J, Kobayashi J. Pyrinadine A, a novel pyridine alkaloid with an azoxy moiety from sponge Cribrochalina sp. Tetrahedron Lett 2006; 47: 997-998

22 Redmond NE, Morrow CC, Thacker RW, Diaz MC, Boury-Esnault N, Cárdenas P, Hajdu E, Lôbo-Hajdu G, Picton BE, Pomponi SA, Kayal E, Collins AG. Phylogeny and systematics of Demospongiae in light of new small-subunit ribosomal DNA (18 S) sequences. Integr Comp Biol 2013; 53: 388-415

$23 \mathrm{Xu}$ NJ, Sun X, Yan XJ. A new cyclostellettamine from sponge Amphimedon compressa. Chin Chem Lett 2007; 18: 947-950

24 Schmitz FJ, Hollenbeak KH, Campbell DC. Marine natural products: halitoxin, toxic complex of several marine sponges of the genus Haliclona. J Org Chem 1978; 43: 3916-3922

25 Thompson MN, Gallimore WA, Townsend MM, Chambers NA, Williams LA. Bioactivity of amphitoxin, the major constituent of the Jamaican sponge Amphimedon compressa. Chem Biodivers 2010; 7: 1904-1910

26 Albrizio S, Ciminiello P, Fattorusso E, Magno S, Pawlik JR. Amphitoxin, a new high molecular weight antifeedant pyridinium salt from the caribbean sponge Amphimedon compressa. J Nat Prod 1995; 58: 647652

27 Talpir R, Rudi A, Ilan M, Kashman Y. Niphatoxin A and B; two new ichthyo- and cytotoxic tripyridine alkaloids from a marine sponge. Tetrahedron Lett 1992; 33: 3033-3034

28 De Oliveira JH, Grube A, Köck M, Berlinck RG, Macedo ML, Ferreira AG, Hajdu E. Ingenamine $\mathrm{G}$ and cyclostellettamines GI, K, and L from the new Brazilian species of marine sponge Pachychalina sp. J Nat Prod 2004; 67: 1685-1689

29 De Oliveira JH, Seleghim MH, Timm C, Grube A, Köck M, Nascimento GG, Martins ACT, Silva EG, de Souza AO, Minarini PR. Antimicrobial and antimycobacterial activity of cyclostellettamine alkaloids from sponge Pachychalina sp. Mar Drugs 2006; 4: 1-8

30 Laville R, Thomas OP, Berrue F, Reyes F, Amade P. Pachychalines A-C: novel 3-alkylpyridinium salts from the marine sponge Pachychalina sp. European J Org Chem 2008; 2008: 121-125

31 Buchanan MS, Carroll AR, Addepalli R, Avery VM, Hooper JNA, Quinn RJ. Niphatoxin C, a cytotoxic tripyridine alkaloid from Callyspongia sp. J Nat Prod 2007; 70: 2040-2041
32 Torres YR, Berlinck RG, Magalhães A, Schefer AB, Ferreira AG, Hajdu E, Muricy G. Arenosclerins A-C and haliclonacyclamine E, new tetracyclic alkaloids from a Brazilian endemic Haplosclerid sponge Arenosclera brasiliensis. J Nat Prod 2000; 63: 1098-1105

33 Torres YR, Berlinck RG, Nascimento GG, Fortier SC, Pessoa C, de Moraes MO. Antibacterial activity against resistant bacteria and cytotoxicity of four alkaloid toxins isolated from the marine sponge Arenosclera brasiliensis. Toxicon 2002; 40: 885-891

34 Thacker RW, Hill AL, Hill MS, Redmond NE, Collins AG, Morrow CC, Spicer L, Carmack CA, Zappe ME, Pohlmann D, Hall C, Diaz MC, Bangalore PV. Nearly complete $28 \mathrm{~S}$ rRNA gene sequences confirm new hypotheses of sponge evolution. Integr Comp Biol 2013; 53: 373-387

35 Schmidt G, Timm C, Koeck M. Haliclocyclin C, a new monomeric 3-alkyl pyridinium alkaloid from the arctic marine sponge Haliclona viscosa. Z Naturforsch B 2011; 66: 745-748

36 Timm C, Volk C, Sasse F, Köck M. The first cyclic monomeric 3-alkylpyridinium alkaloid from natural sources: identification, synthesis, and biological activity. Org Biomol Chem 2008; 6: 4036-4040

37 Schmidt G, Timm C, Grube A, Volk CA, Köck M. Viscosalines B $(1,2)$ and E $(1,2)$ : challenging new 3 -alkyl pyridinium alkaloids from the marine sponge Haliclona viscosa. Chemistry 2012; 18: 8180-8189

38 Volk CA, Köck M. Viscosamine: the first naturally occurring trimeric $3-$ alkyl pyridinium alkaloid. Org Lett 2003; 5: 3567-3569

39 Teruya T, Kobayashi K, Suenaga K, Kigoshi H. Cyclohaliclonamines A-E: dimeric, trimeric, tetrameric, pentameric, and hexameric 3-alkyl pyridinium alkaloids from a marine sponge Haliclona sp. J Nat Prod 2006; 69: $135-137$

40 Casapullo A, Pinto OC, Marzocco S, Autore G, Riccio R. 3-Alkylpyridinium alkaloids from the pacific sponge Haliclona sp. J Nat Prod 2009; 72: 301-303

41 Lee Y, Jang KH, Jeon JE, Yang WY, Sim CJ, Oh KB, Shin J. Cyclic Bis-1, 3dialkylpyridiniums from the sponge Haliclona sp. Mar Drugs 2012; 10: $2126-2137$

42 Damodaran V, Ryan JL, Keyzers RA. Cyclic 3-alkyl pyridinium alkaloid monomers from a New Zealand Haliclona -++-. marine sponge. J Nat Prod 2013; 76: 1997-2001

43 Laville R, Genta-Jouve G, Urda C, Fernandez R, Thomas OP, Reyes $F$ Amade P. Njaoaminiums A, B, and C: cyclic 3-alkylpyridinium salts from the marine sponge Reniera sp. Molecules 2009; 14: 4716-4724

44 Laville R, Amade P, Thomas OP. 3-Alkylpyridinium salts from Haplosclerida marine sponges: isolation, structure elucidations, and biosynthetic considerations. Pure Appl Chem 2009; 81: 1033-1040

45 Baker BJ, Scheuer PJ, Shoolery JN. Papuamine, an antifungal pentacyclic alkaloid from a marine sponge, Haliclona sp. J Am Chem Soc 1988; 110 : 965-966

46 Fahy E, Molinski TF, Harper MK, Sullivan BW, Faulkner DJ, Parkanyi L, Clardy J. Haliclonadiamine, an antimicrobial alkaloid from the sponge Haliclona sp. Tetrahedron Lett 1988; 29: 3427-3428

47 Kashman Y, Koren-Goldshlager G, Gravalos MDG, Schleyer M. Halitulin, a new cytotoxic alkaloid from the marine sponge Haliclona tulearensis. Tetrahedron Lett 1999; 40: 997-1000

48 Sorek H, Rudi A, Aknin M, Gaydou EM, Kashman Y. Isohalitulin and haliclorensins B and C, three marine alkaloids from Haliclona tulearensis. J Nat Prod 2010; 73: 456-458

49 Heinrich MR, Kashman Y, Spiteller P, Steglich W. Revision of the structure of haliclorensin to (S)-7-methyl-1,5-diazacyclotetradecane and confirmation of the new structure by synthesis. Tetrahedron 2001; 57: 9973-9978

50 Koren-Goldshlager G, Kashman Y, Schleyer M. Haliclorensin, a novel diamino alkaloid from the marine sponge Haliclona tulearensis. J Nat Prod 1998; 61: 282-284

51 Fusetani N, Yasumuro K, Matsunaga S, Hirota H. Haliclamines A and B, cytotoxic macrocyclic alkaloids from a sponge of the genus Haliclona. Tetrahedron Lett 1989; 30: 6891-6894

52 Schmidt G, Timm C, Kock M. New haliclamines E and F from the Arctic sponge Haliclona viscosa. Org Biomol Chem 2009; 7: 3061-3064

53 Volk CA, Lippert H, Lichte E, Köck $M$. Two new haliclamines from the Arctic sponge Haliclona viscosa. Eur J Org Chem 2004; 2004: $3154-$ 3158

54 Cychon C, Schmidt G, Mordhorst T, Koeck M. Structure elucidation of submilligram quantities of natural products - application to haliclamines $\mathrm{G}$ and $\mathrm{H}$ from the Arctic marine sponge Haliclona viscosa. Z Naturforsch B 2012; 67: 944-950 
55 Jaspars $M$, Pasupathy $V$, Crews $P$. A tetracyclic diamine alkaloid, halicyclamine A, from the marine sponge Haliclona sp. J Org Chem 1994; 59: 3253-3255

56 Arai M, Liu L, Fujimoto T, Setiawan A, Kobayashi M. DedA protein relates to action-mechanism of halicyclamine A, a marine spongean macrocyclic alkaloid, as an anti-dormant mycobacterial substance. Mar Drugs 2011; 9: 984-993

57 Arai M, Sobou M, Vilchéze C, Baughn A, Hashizume H, Pruksakorn P, Ishida S, Matsumoto M, Jacobs jr. WR, Kobayashi M. Halicyclamine A, a marine spongean alkaloid as a lead for anti-tuberculosis agent. Bioorg Med Chem 2008; 16: 6732-6736

58 Charan RD, Garson MJ, Brereton IM, Willis AC, Hooper JNA. Haliclonacyclamines A and B, cytotoxic alkaloids from the tropical marine sponge Haliclona sp. Tetrahedron 1996; 52: 9111-9120

59 Clark RJ, Field KL, Charan RD, Garson MJ, Brereton M, Willis AC. The haliclonacyclamines, cytotoxic tertiary alkaloids from the tropical marine sponge Haliclona sp. Tetrahedron 1998; 54: 8811-8826

60 Matsunaga S, Miyata Y, van Soest RW, Fusetani N. Tetradehydrohalicyclamine $\mathrm{A}$ and 22-Hydroxyhalicyclamine $\mathrm{A}$, new cytotoxic bispiperidine alkaloids from a marine sponge Amphimedon sp. J Nat Prod 2004; 67: 1758-1760

61 De Oliveira JH, Nascimento AM, Kossuga MH, Cavalcanti BC, Pessoa CO, Moraes MO, Macedo ML, Ferreira AG, Hajdu E, Pinheiro US. Cytotoxic alkylpiperidine alkaloids from the Brazilian marine sponge Pachychalina alcaloidifera. J Nat Prod 2007; 70: 538-543

62 Dewi AS, Hadi TA, Fajarningsih ND, Blanchfield JT, Bernhardt PV, Garson MJ. Acanthocyclamine A from the Indonesian marine sponge Acanthostrongylophora ingens. Aust J Chem 2014; 67: 1205-1210

63 Nakagawa M, Endo M, Tanaka N, Gen-Pei L. Structures of xestospongin $\mathrm{A}, \mathrm{B}, \mathrm{C}$ and $\mathrm{D}$, novel vasodilative compounds from marine sponge, Xestospongia exigua. Tetrahedron Lett 1984; 25: 3227-3230

64 Kobayashi M, Kawazoe K, Kitagawa I. Araguspongines B, C, D, E, F, G, H, and $\mathrm{J}$, new vasodilative bis-1-oxaquinolizidine alkaloids from an Okinawan marine sponge, Xestospongia sp. Chem Pharm Bull (Tokyo) 1989; 37: 1676-1678

65 Quirion JC, Sevenet T, Husson HP, Weniger B, Debitus C. Two new alkaloids from Xestospongia sp., a New Caledonian sponge. J Nat Prod 1992; 55: 1505-1508

66 Venkateswarlu Y, Reddy MVR, Rao JV. Bis-1-oxaquinolizidines from the sponge Haliclona exigua. J Nat Prod 1994; 57: 1283-1285

67 Liu H, Mishima Y, Fujiwara T, Nagai H, Kitazawa A, Mine Y, Kobayashi H, Yao $X$, Yamada J, Oda T. Isolation of araguspongine $M$, a new stereoisomer of an araguspongine/xestospongin alkaloid, and dopamine from the marine sponge Neopetrosia exigua collected in Palau. Mar Drugs 2004; 2: 154-163

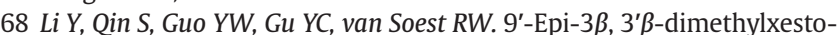
spongin $C$, a new macrocyclic diamine alkaloid from the Hainan sponge Neopetrosia exigua. Planta Med 2011; 77: 179-181

69 Wei X, Nieves K, Rodríguez AD. Neopetrosiamine A, biologically active bis-piperidine alkaloid from the Caribbean sea sponge Neopetrosia proxima. Bioorg Med Chem Lett 2010; 20: 5905-5908

70 Morinaka BI, Molinski TF. Xestoproxamines A-C from Neopetrosia proxima. Assignment of absolute stereostructure of bis-piperidine alkaloids by integrated degradation-CD analysis. J Nat Prod 2011; 74: 430-440

71 Braekman JC, Daloze D, Cimino G, Trivellone E. 2D-NMR study of petrosins: Revised structure for petrosin-A. Bull Soc Chim Belg 1988; 97: 519-524

72 Braekman JC, Daloze D, Defay N, Zimmermann D. Petrosin-A and -B, two new bis-quinolizidine alkaloids from the sponge Petrosia seriata. Bull Soc Chim Belg 1984; 93: 941-944

73 Defant A, Mancini I, Raspor L, Guella G, Turk T, Sepčić K. New structural insights into saraines A, B, and C, macrocyclic alkaloids from the mediterranean sponge Reniera (Haliclona) sarai. Eur J Org Chem 2011; 2011: 3761-3767

74 Cimino G, Stefano SD, Scognamiglio G, Sodano G, Trivellone E. Sarains: A new class of alkaloids from the marine sponge Reniera sarai. Bull Soc Chim Belg 1986; 95: 783-800

75 Caprioli V, Cimino G, de Giulio A, Madaio A, Scognamiglio G, Trivellone E. Selected biological activities of saraines. Comp Biochem Physiol B 1992; 103: 293-296

76 Jang KH, Kang GW, Jeon JE, Lim C, Lee HS, Sim CJ, Oh KB, Shin J. Haliclonin A, a new macrocyclic diamide from the sponge Haliclona sp. Org Lett 2009; 11: 1713-1716
77 Sorek H, Rudi A, Benayahu Y, Kashman Y. Njaoamines G and H, two new cytotoxic polycyclic alkaloids and a tetrahydroquinolone from the marine sponge Neopetrosia sp. Tetrahedron Lett 2007; 48: 76917694

78 Reyes F, Fernández R, Urda C, Francesch A, Bueno S, de Eguilior C, Cuevas $C$. Njaoamines A-F, new cytotoxic polycyclic alkaloids from the haplosclerid sponge Reniera sp. Tetrahedron 2007; 63: 24322438

79 Hwang BS, Oh JS, Jeong EJ, Sim CJ, Rho JR. Densanins A and B, new macrocyclic pyrrole alkaloids isolated from the marine sponge Haliclona densaspicula. Org Lett 2012; 14: 6154-6157

80 Cavalcanti BC, Sombra CML, de Oliveira JH, Berlinck RG, de Moraes MO, Pessoa $C$. Cytotoxicity and genotoxicity of ingenamine $G$ isolated from the Brazilian marine sponge Pachychalina alcaloidifera. Comp Biochem Physiol C Toxicol Pharmacol 2008; 147: 409-415

81 Sakai R, Kohmoto S, Higa T, Jefford CW, Bernardinelli G. Manzamine B and $C$, two novel alkaloids from the sponge Haliclona sp. Tetrahedron Lett 1987; 28: 5493-5496

82 Sakai R, Higa T, Jefford CW, Bernardinelli G. Manzamine A, a novel antitumor alkaloid from a sponge. J Am Chem Soc 1986; 108: 6404-6405

83 Ashok P, Ganguly S, Murugesan S. Manzamine alkaloids: isolation, cytotoxicity, antimalarial activity and SAR studies. Drug Discov Today 2014; 19: 1781-1791

84 Kobayashi M, Chen YJ, Aoki S, In Y, Ishida T, Kitagawa I. Four new $\beta$ carboline alkaloids isolated from two Okinawan marine sponges of Xestospongia sp. and Haliclona sp. Tetrahedron 1995; 51: 3727-3736

85 Nakamura H, Deng S, Kobayashi J, Ohizumi Y, Tomotake Y, Matsuzaki T, Hirata $Y$. Keramamine-A and -B, novel antimicrobial alkaloids from the Okinawan marine sponge Pellina sp. Tetrahedron Lett 1987; 28: 621-624

86 Ichiba T, Sakai R, Kohmoto S, Saucy G, Higa T. New manzamine alkaloids from a sponge of the genus Xestospongia. Tetrahedron Lett 1988; 29: 3083-3086

87 Kobayashi J, Tsuda M, Kawasaki N, Sasaki T, Mikami Y. 6-Hydroxymanzamine A and 3, 4-dihydromanzamine A, new alkaloids from the Okinawan marine sponge Amphimedon sp. J Nat Prod 1994; 57: 17371740

88 Kobayashi J, Tsuda M, Kawasaki N, Matsumoto K, Adachi T. Keramaphidin B, a novel pentacyclic alkaloid from a marine sponge Amphimedon sp.: A plausible biogenetic precursor of manzamine alkaloids. Tetrahedron Lett 1994; 35: 4383-4386

89 Tsuda M, Kawasaki N, Kobayashi J. Keramaphidin C and keramamine C plausible biogenetic precursors of manzamine $C$ from an Okinawan marine sponge. Tetrahedron Lett 1994; 35: 4387-4388

90 Tsuda M, Kawasaki N, Kobayashi J. Ircinols A and B, first antipodes of manzamine-related alkaloids from an Okinawan marine sponge. Tetrahedron 1994; 50: 7957-7960

91 Tsuda M, Inaba K, Kawasaki N, Honma K, Kobayashi J. Chiral resolution of ( \pm )-keramaphidin B and isolation of manzamine L, a new $\beta$-carboline alkaloid from a sponge Amphimedon sp. Tetrahedron 1996; 52: 2319-2324

92 Watanabe D, Tsuda M, Kobayashi J. Three new manzamine congeners from Amphimedon sponge. J Nat Prod 1998; 61: 689-692

93 Takahashi Y, Kubota T, Fromont J, Kobayashi J. Zamamidines A and B, new manzamine alkaloids from the sponge Amphimedon species. Org Lett 2008; 11: 21-24

94 Kubota T, Kamijyo Y, Takahashi-Nakaguchi A, Fromont J, Gonoi T, Kobayashi J. Zamamiphidin A, a new manzamine related alkaloid from an Okinawan marine sponge Amphimedon sp. Org Lett 2013; 15: 610-612

95 Rao KV, Kasanah N, Wahyuono S, Tekwani BL, Schinazi RF, Hamann MT. Three new manzamine alkaloids from a common Indonesian sponge and their activity against infectious and tropical parasitic diseases. J Nat Prod 2004; 67: 1314-1318

96 Rao KV, Donia MS, Peng J, Garcia-Palomero E, Alonso D, Martinez A, Medina M, Franzblau SG, Tekwani BL, Khan SI. Manzamine B and E and ircinal A related alkaloids from an Indonesian Acanthostrongylophora sponge and their activity against infectious, tropical parasitic, and Alzheimer's diseases. J Nat Prod 2006; 69: 1034-1040

97 Wahba AE, Fromentin Y, Zou Y, Hamann MT. Acantholactone, a new manzamine related alkaloid with an unprecedented $\delta$-lactone and $\varepsilon$ lactam ring system. Tetrahedron Lett 2012; 53: 6329-6331

98 El Sayed KA, Kelly M, Kara UAK, Ang KKH, Katsuyama I, Dunbar DC, Khan AA, Hamann MT. New manzamine alkaloids with potent activity against infectious diseases. J Am Chem Soc 2001; 123: 1804-1808 
99 Samoylenko V, Khan SI, Jacob MR, Tekwani BL, Walker LA, Hufford CD, Muhammad I. Bioactive (+)-manzamine A and (+)-8-hydroxymanzamine A tertiary bases and salts from Acanthostrongylophora ingens and their preparations. Nat Prod Commun 2009; 4: 185-192

100 Furusato A, Kato H, Nehira T, Eguchi K, Kawabata T, Fujiwara Y, Losung F, Mangindaan RE, de Voogd NJ, Takeya M. Acanthomanzamines A-E with new manzamine frameworks from the marine sponge Acanthostrongylophora ingens. Org Lett 2014; 16: 3888-3891

101 El-Desoky AH, Kato H, Eguchi K, Kawabata T, Fujiwara Y, Losung F Mangindaan RE, de Voogd NJ, Takeya M, Yokosawa H. Acantholactam and pre-neo-kauluamine, manzamine-related alkaloids from the Indonesian marine sponge Acanthostrongylophora ingens. J Nat Prod 2014; 77: 1536-1540

102 Rodríguez J, Crews P. Revised structure of xestocyclamine A and description of a new analogue. Tetrahedron Lett 1994; 35: 4719-4722

103 Rodriguez J, Peters BM, Kurz L, Schatzman RC, McCarley D, Lou L, Crews $P$. An alkaloid protein kinase $C$ inhibitor, xestocyclamine $A$, from the marine sponge Xestospongia sp. J Am Chem Soc 1993; 115: 10436-10437

104 Kong F, Andersen RJ, Allen TM. Ingenamine, a novel pentacyclic alkaloid from the marine sponge Xestospongia ingens. Tetrahedron Lett 1994; 35: 1643-1646

105 Kong F, Andersen RJ, Allen TM. Ingamines A and B, new cytotoxic alkaloids from the marine sponge Xestospongia ingens. Tetrahedron 1994; 50: 6137-6144

106 Kong F, Andersen RJ, Allen TM. Madangamine A, a novel cytotoxic alkaloid from the marine sponge Xestospongia ingens. J Am Chem Soc 1994; 116: 6007-6008

107 Kong F, Andersen RJ. Ingenamine alkaloids isolated from the sponge Xestospongia ingens: Structures and absolute configurations. Tetrahedron 1995; 51: 2895-2906

108 Ichiba T, Corgiat JM, Scheuer PJ, Kelly-Borges M. 8-Hydroxymanzamine A, a $\beta$-carboline alkaloid from a sponge, Pachypellina sp. J Nat Prod 1994; 57: 168-170

109 Umeyama A, Nagano C, Arihara S. Three novel C21 polyacetylenes from the marine sponge Callyspongia sp. J Nat Prod 1997; 60: 131133

110 Youssef DTA, Yoshida WY, Kelly M, Scheuer PJ. Polyacetylenes from a Red Sea sponge Callyspongia species. J Nat Prod 2000; 63: 1406-1410

111 Nakao Y, Uehara T, Matunaga S, Fusetani N, van Soest RWM. Callyspongynic acid, a polyacetylenic acid which inhibits $\alpha$-glucosidase, from the marine sponge Callyspongia truncata. J Nat Prod 2002; 65: 922924

112 Braekman JC, Daloze D, Devijver C, Dubut D, van Soest RWM. A new C-20 polyacetylene from the sponge Callyspongia pseudoreticulata. J Nat Prod 2003; 66: 871-872

113 Youssef DTA, van Soest RWM, Fusetani N. Callyspongamide A, a new cytotoxic polyacetylenic amide from the Red Sea sponge Callyspongia fistularis. J Nat Prod 2003; 66: 861-862

114 Youssef DT, van Soest RWM, Fusetani N. Callyspongenols A-C, new cytotoxic C22-polyacetylenic alcohols from a Red Sea sponge, Callyspongia species. J Nat Prod 2003; 66: 679-681

115 Umeyama A, Matsuoka N, Mine R, Nakata A, Arimoto E, Matsui M, Shoji N, Arihara S, Takei M, Hashimoto T. Polyacetylene diols with antiproliferative and driving Th1 polarization effects from the marine sponge Callyspongia sp. J Nat Med 2010; 64: 93-97

116 Rotem M, Kashman Y. New polyacetylenes from the sponge Siphonochalina sp. Tetrahedron Lett 1979; 20: 3193-3196

117 Tada H, Yasuda F. Siphonodiol, a new polyacetylenic metabolite from the sponge Siphonochalina truncate. Chem Lett 1984; 13: 779-780

118 Ayyad SE, Angawy R, Saqer EA, Badria FA. Cytotoxic polyacetylenes from the Red Sea sponge Siphonochalina siphonella. Z Naturforsch C 2014; 69: 117-123

119 Cimino G, de Stefano S. New acetylenic compounds from the sponge Reniera fulva. Tetrahedron Lett 1977; 18: 1325-1328

120 Ortega MJ, Zubía E, Carballo JL, Salvá J. Fulvinol, a new long-chain diacetylenic metabolite from the sponge Reniera fulva. J Nat Prod 1996; 59: 1069-1071

121 Nuzzo G, Ciavatta ML, Villani G, Manzo E, Zanfardino A, Varcamonti M, Gavagnin $M$. Fulvynes, antimicrobial polyoxygenated acetylenes from the Mediterranean sponge Haliclona fulva. Tetrahedron 2012; 68: 754-760

122 Williams DH, Faulkner DJ. Three new acetylenes from the Palauan sponge Haliclona sp. J Nat Prod 1996; 59: 1099-1101
123 Shin J, Seo Y, Cho KW, Rho JR, Paul VJ. Osirisynes A-F, highly oxygenated polyacetylenes from the sponge Haliclona osiris. Tetrahedron 1998; 54: 8711-8720

124 Chill L, Miroz A, Kashman Y. Haliclonyne, a new highly oxygenated polyacetylene from the marine sponge Haliclona species. J Nat Prod 2000; 63: 523-526

125 Aoki S, Matsui K, Tanaka K, Satari R, Kobayashi M. Lembehyne A, a novel neuritogenic polyacetylene, from a marine sponge of Haliclona sp. Tetrahedron 2000; 56: 9945-9948

126 Aoki S, Matsui K, Wei H, Murakami N, Kobayashi M. Structure-activity relationship of neuritogenic spongean acetylene alcohols, lembehynes. Tetrahedron 2002; 58: 5417-5422

127 Zhou GX, Molinski T. Long-chain acetylenic ketones from the Micronesian sponge Haliclona sp. Importance of the 1-yn-3-ol group for antitumor activity. Mar Drugs 2003; 1: 46-53

128 Aratake S, Trianto A, Hanif $N$, de Voogd $N$, Tanaka J. A new polyunsaturated brominated fatty acid from a Haliclona sponge. Mar Drugs 2009; 7: 523-527

129 Kobayashi M, Mahmud T, Tajima H, Wang W, Aoki S, Nakagawa S, Mayumi T, Kitagawa I. Marine natural products. XXXVI. Biologically active polyacetylenes, adociacetylenes $\mathrm{A}, \mathrm{B}, \mathrm{C}$, and $\mathrm{D}$, from an Okinawan marine sponge of Adocia sp. Chem Pharm Bull 1996; 44: 720-724

130 Wright AE, McConnell OJ, Kohmoto S, Lui MS, Thompson W, Snader KM. Duryne, a new cytotoxic agent from the marine sponge Cribrochalina dura. Tetrahedron Lett 1987; 28: 1377-1379

131 Gunasekera SP, Faircloth GT. New acetylenic alcohols from the sponge Cribrochalina vasculum. J Org Chem 1990; 55: 6223-6225

132 Aiello A, Fattorusso E, Menna M, Pansini M. Further bioactive acetylenic compounds from the caribbean sponge Cribrochalina vasculum. J Nat Prod 1992; 55: 1275-1280

133 Hallock YF, Cardellina JH, Balaschak MS, Alexander MR, Prather TR, Shoemaker RH, Boyd MR. Antitumor activity and stereochemistry of acetylenic alcohols from the sponge Cribrochalina vasculum. J Nat Prod 1995; 58: 1801-1807

134 Dai JR, Hallock YF, Cardellina JH, Boyd MR. Vasculyne, a new cytotoxic acetylenic alcohol from the marine sponge Cribrochalina vasculum. J Nat Prod 1996; 59: 88-89

135 Legrave N, Hamrouni-Buonomo S, Dufies M, Guérineau V, Vacelet J, Auberger P, Amade P, Mehiri M. Nepheliosyne B, a new polyacetylenic acid from the new caledonian marine sponge Niphates sp. Mar Drugs 2013; 11: 2282-2292

136 De Jesus RP, Faulkner DJ. Chlorinated acetylenes from the San Diego sponge Haliclona lunisimilis. J Nat Prod 2003; 66: 671-674

137 Castiello D, Cimino G, de Rosa S, de Stefano S, Sodano G. High molecular weight polyacetylenes from the nudibranch Peltodoris actromaculata and the sponge Petrosia ficiformis. Tetrahedron Lett 1980; 21: 50475050

138 Cimino G, Crispino A, de Rosa S, de Stefano S, Sodano G. Polyacetylenes from the sponge Petrosia ficiformis found in dark caves. Experientia 1981; 37: 924-926

139 Cimino G, de Giulio A, de Rosa S, de Stefano S, Sodano G. Further high molecular weight polyacetylenes from the sponge Petrosia ficiformis. J Nat Prod 1985; 48: 22-27

140 Cimino G, de Giulio A, de Rosa S, di Marzo V. High molecular weight polyacetylenes from Petrosia ficiformis: Further structural analysis and biological activity. Tetrahedron Lett 1989; 30: 3563-3566

141 Cimino G, de Giulio A, de Rosa S, di Marzo V. Minor bioactive polyacetylenes from Petrosia ficiformis. J Nat Prod 1990; 53: 345-353

142 Guo Y, Gavagnin M, Trivellone E, Cimino G. Absolute stereochemistry of petroformynes, high molecular polyacetylenes from the marine sponge Petrosia ficiformis. Tetrahedron 1994; 50: 13261-13268

143 Guo Y, Gavagnin M, Trivellone E, Cimino G. Further structural studies on the petroformynes. J Nat Prod 1995; 58: 712-722

144 Guo Y, Gavagnin M, Salierno C, Cimino G. Further petroformynes from both Atlantic and Mediterranean populations of the sponge Petrosia ficiformis. J Nat Prod 1998; 61: 333-337

145 Isaacs S, Kashman Y, Loya S, Hizi A, Loya Y. Petrosynol and petrosolic acid, two novel natural inhibitors of the reverse transcriptase of human immunodeficiency virus from Petrosia sp. Tetrahedron 1993; 49: $10435-10438$

146 Guerriero A, Debitus C, Laurent D, d'Ambrosio M, Pietra F. Aztèquynol $A$, the first clearly defined, C-branched polyacetylene and the analogue Aztèquynol B. Isolation from the tropical marine sponge Petrosia sp. Tetrahedron Lett 1998; 39: 6395-6398 
147 Fusetani N, Shiragaki T, Matsunaga S, Hashimoto K. Bioactive marine metabolites XX. Petrosynol and petrosynone, antimicrobial C30 polyacetylenes from the marine sponge Petrosia sp.: Determination of the absolute configuration. Tetrahedron Lett 1987; 28: 4313-4314

148 Fusetani N, Li HY, Tamura K, Matsunaga S. Antifungal brominated C18 acetylenic acids from the marine sponge, Petrosia volcano Hoshino. Tetrahedron 1993; 49: 1203-1210

149 Li H-Y, Matsunaga S, Fusetani N. Corticatic acids A-C, antifungal acetylenic acids from the marine sponge, Petrosia corticata. J Nat Prod 1994; 57: 1464-1467

150 Nishimura S, Matsunaga S, Shibazaki M, Suzuki K, Harada N, Naoki H, Fusetani $N$. Corticatic acids D and E, polyacetylenic geranylgeranyltransferase type I inhibitors, from the marine sponge Petrosia corticata. J Nat Prod 2002; 65: 1353-1356

151 Shin J, Seo Y, Cho KW. Five new polyacetylenes from a ponge of the genus Petrosia. J Nat Prod 1998; 61: 1268-1273

152 Seo Y, Cho KW, Rho J-R, Shin J, Sim CJ. Petrocortynes and petrosiacetylenes, novel polyacetylenes from a sponge of the genus Petrosia. Tetrahedron 1998; 54: 447-462

153 Kim JS, Lim YJ, Im KS, Jung JH, Shim CJ, Lee CO, Hong J, Lee H. Cytotoxic polyacetylenes from the marine sponge Petrosia sp. J Nat Prod 1999; 62: 554-559

154 Lim YJ, Lee CO, Hong J, Kim DK, Im KS, Jung JH. Cytotoxic polyacetylenic alcohols from the marine sponge Petrosia species. J Nat Prod 2001; 64: 1565-1567

155 Lim YJ, Park HS, Im KS, Lee CO, Hong J, Lee MY, Kim DK, Jung JH. Additional cytotoxic polyacetylenes from the marine sponge Petrosia species. J Nat Prod 2001; 64: 46-53

156 Lee YJ, Yoo SJ, Kang JS, Yun J, Shin HJ, Lee JS, Lee HS. Cytotoxic petrosiacetylenes from the marine sponge Petrosia sp. Lipids 2013; 48 : 87-91

157 Juan YS, Lee CC, Tsao CW, Lu MC, El-Shazly M, Shih HC, Chen YC, Wu YC, $\mathrm{Su} J H$. Structure elucidation and cytotoxic evaluation of new polyacetylenes from a marine sponge Petrosia sp. Int J Mol Sci 2014; 15: 16511-16521

158 Watanabe K, Tsuda Y, Hamada M, Omori M, Mori G, Iguchi K, Naoki H, Fujita T, van Soest RW. Acetylenic strongylodiols from a Petrosia (Strongylophora) Okinawan marine sponge. J Nat Prod 2005; 68: 1001-1005

159 Watanabe K, Mori G, Iguchi K, Suzuki M, van Soest RW. Nine acetylenic alcohols isolated from the Okinawan marine sponge of the genus Petrosia (Strongylophora). Nat Prod Res 2007; 21: 710-720

160 Okamoto C, Nakao Y, Fujita T, Iwashita T, van Soest RWM, Fusetani N, Matsunaga S. Cytotoxic C47-polyacetylene carboxylic acids from a marine sponge Petrosia sp. J Nat Prod 2007; 70: 1816-1819

161 Ueoka R, Ise Y, Matsunaga S. Cytotoxic polyacetylenes related to petroformyne-1 from the marine sponge Petrosia sp. Tetrahedron 2009; 65: 5204-5208

162 Hitora Y, Takada K, Okada S, Matsunaga S. Miyakosynes A-F, cytotoxic methyl branched acetylenes from a marine sponge Petrosia sp. Tetrahedron 2011; 67: 4530-4534

163 Ohta S, Ogawa T, Ohta E, Ikeuchi T, Kamemura K, Ikegami S. Petroacetylene, a new polyacetylene from the marine sponge Petrosia soli- da that inhibits blastulation of starfish embryos. Nat Prod Res 2013; 27: 1842-1847

164 Horikawa K, Yagyu T, Yoshioka Y, Fujiwara T, Kanamoto A, Okamoto T, Ojika M. Petrosiols A-E, neurotrophic diyne tetraols isolated from the Okinawan sponge Petrosia strongylata. Tetrahedron 2013; 69: 101106

165 Schmitz FJ, Gopichand Y. (7E,13乡,15Z)-14,16-dibromo-7,13,15-hexadecatrien-5-ynoic acid. A novel dibromo acetylenic acid from the marine sponge Xestospongia muta. Tetrahedron Lett 1978; 19: 3637 3640

166 Quinn RJ, Tucker DJ. A brominated bisacetylenic acid from the marine sponge Xestospongia testudinaria. Tetrahedron Lett 1985; 26: 16711672

167 Quinn RJ, Tucker DJ. Further acetylenic acids from the marine sponge Xestospongia testudinaria. J Nat Prod 1991; 54: 290-294

168 Bourguet-Kondracki ML, Rakotoarisoa MT, Martin MT, Guyot M. Bioactive bromopolyacetylenes from the marine sponge Xestospongia testudinaria. Tetrahedron Lett 1992; 33: 225-226

169 Hirsh S, Carmely S, Kashman Y. Brominated unsaturated acids from the marine sponge Xestospongia sp. Tetrahedron 1987; 43: 3257-3261

170 Quiñoà E, Crews P. Melynes, polyacetylene constituents from a Vanuatu marine sponge. Tetrahedron Lett 1988; 29: 2037-2040

171 Kobayashi J, Naitoh K, Ishida K, Shigemori H, Ishibashi M. Nepheliosyne A, new C47 acetylenic acid from the okinawan marine sponge Xestospongia sp. J Nat Prod 1994; 57: 1300-1303

172 Brantley SE, Molinski TF, Preston CM, DeLong EF. Brominated acetylenic fatty acids from Xestospongia sp., a marine spongebacteria association. Tetrahedron 1995; 51: 7667-7672

173 Dai JR, Hallock YF, Cardellina JH, Gray GN, Boyd MR. Triangulynes A-H and triangulynic acid, new cytotoxic polyacetylenes from the marine sponge Pellina triangulata. J Nat Prod 1996; 59: 860-865

174 Fu X, Abbas SA, Schmitz FJ, Vidavsky I, Gross ML, Laney $M$, Schatzman RC, Cabuslay RD. New acetylenic metabolites from the marine sponge Pellina triangulata. Tetrahedron 1997; 53: 799-814

175 Matsunaga S, Okada Y, Fusetani N, van Soest RWM. An antimicrobial C14 acetylenic acid from a marine sponge Oceanapia species. J Nat Prod 2000; 63: 690-691

176 Erpenbeck D, van Soest RWM. Status and perspective of sponge chemosystematics. Mar Biotechnol 2007; 9: 2-19

177 Montalvo NF, Hill RT. Sponge-associated bacteria are strictly maintained in two closely related but geographically distant sponge hosts. Appl Environ Microbiol 2011; 77: 7207-7216

178 Trindade-Silva $A E$, Rua $C$, Silva GGZ, Dutilh BE, Moreira APB, Edwards RA, Hajdu E, Lobo-Hajdu G, Vasconcelos AT, Berlinck RGS, Thompson FL. Taxonomic and functional microbial signatures of the endemic marine sponge Arenosclera brasiliensis. PLoS One 2012; 7 : e39905

179 Khan ST, Musarrat J, Alkhedhairy AA, Kazuo S. Diversity of bacteria and polyketide synthase associated with marine sponge Haliclona sp. Ann Microbiol 2014; 64: 199-207

180 Jasmin C, Anas A, Nair S. Bacterial diversity associated with Cinachyra cavernosa and Haliclona pigmentifera, cohabiting sponges in the Coral Reef Ecosystem of Gulf of Mannar, Southeast Coast of India. PLoS One 2015; 10: e0123222 